\title{
Ethylene Oxidation in a Well-Stirred Reactor
}

\author{
Nick M. Marinov \\ Lawrence Livermore National Laboratory \\ P.O. Box 808, L-298 \\ Livermore, California 94551 \\ Philip C. Malte \\ Combustion Laboratories \\ RECEIVED \\ OCT 131995 \\ OSTI \\ Department of Mechanical Engineering, FU-10 \\ University of Washington \\ Seattle, Washington 98195
}

October 1994

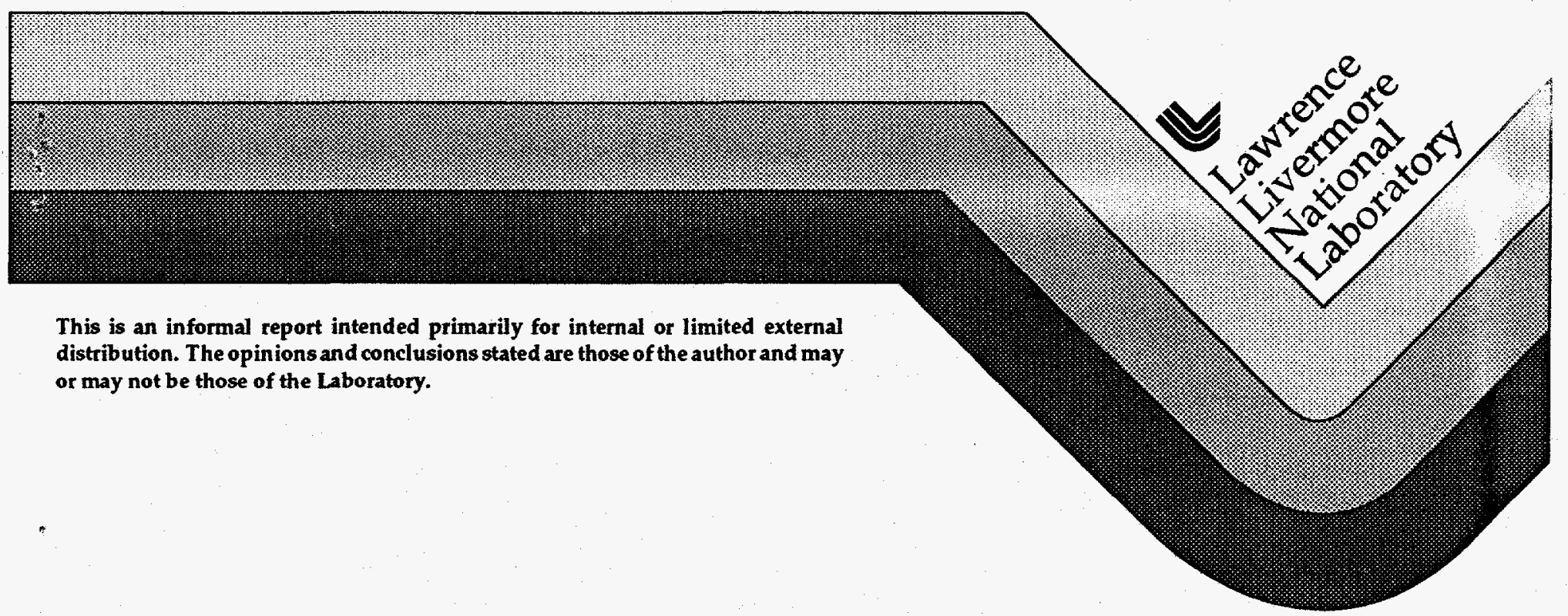




\section{DISCLAMER}

This document was prepared as an account of work sponsored by an agency of the United States Covernment. Neither the United States Covernment nor the University of California nor any of their employees, makes any warranty, express or implied, or assumes any legal liability or responsibility for the accuracy, completeness, or usefulness of any information, apparatus, product, or process disclosed or represents that its use would not infringe privately owred rights. Reference herein to any specific commercial product, process, or service by trade name, trademark, manufacturer, or otherwise, does not necessarily constitute or imply its endorsement, recommendation, or favoring by the United States Covernment or the University of California. The views and opinions of authors expressed herein do not necessarily state or reflect those of the United States Covernment or the University of California, and stall not be used for advertising or product endorsement purposes.

This report has been reproduced directly from the best available copy.

Available to DOE and DOE contractors from the Office of Scientific and Technical Information

P.O. Box 62, Oak Ridge, TN 37831

Prices available from (615) 576-8401, FTS 626-8401

$$
\begin{aligned}
& \text { ! }
\end{aligned}
$$

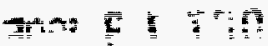

$$
\begin{aligned}
& \div \div
\end{aligned}
$$$$
\text { Available to the public from the }
$$$$
\text { National Technical Information Service }
$$$$
\text { U.S. Department of Commerce }
$$$$
5285 \text { Port Royal Rd. }
$$$$
\text { Springfield, VA } 22161
$$ 


\section{DISCLAIMER}

Portions of this document may be illegible in electronic image products. Images are produced from the best available original document. 


\title{
ETHYLENE OXIDATION IN A WELL-STIRRED REACTOR
}

\author{
Nick M. Marinov \\ Lawrence Livermore National Laboratory \\ P.O. Box 808 \\ Livermore, California 94551 \\ and \\ Philip C. Malte \\ Combustion Laboratories \\ Department Of Mechanical Engineering, FU-10 \\ University of Washington \\ Seattle, Washington 98195
}

Correspondence should be addressed to:

Nick Marinov

Lawrence Livermore National Laboratory

P.O. Box 808

Mail Stop: L -298

Livermore, California 94551

Phone: (510) 424-5463

Fax: (510) 422-2851

Internet E-Mail: marinov@llnl.gov 


\title{
ETHYLENE OXIDATION \\ IN A WELL-STIRRED REACTOR
}

\begin{abstract}
The detailed ethylene oxidation data set of Thornton [1], obtained for a well-stirred reactor operated fuel-lean at atmospheric pressure and for temperatures of $1003 \mathrm{~K}$ to $1253 \mathrm{~K}$, is used as a basis for the comparison of chemical kinetic mechanisms reported in the literature and for the development of a new ethylene oxidation mechanism. The mechanisms examined are those of Westbrook and Pitz [2] and Dagaut et al. [3]. These mechanisms indicated that unusually. large rates for the vinyl decomposition reaction are required to obtain agreement with the Thornton data set.
\end{abstract}

A new ethylene oxidation mechanism is developed in order to overcome some of the drawbacks of the previous mechanisms. The new mechanism closely simulates the overall rate of loss of ethylene, and the concentation of $\mathrm{CO}, \mathrm{CO}_{2}, \mathrm{H}_{2}, \mathrm{CH}_{2} \mathrm{O}, \mathrm{C}_{2} \mathrm{H}_{2}, \mathrm{CH}_{3} \mathrm{OH}, \mathrm{CH}_{4}$, and $\mathrm{C}_{2} \mathrm{H}_{6}$ measured for the stirred reactor. Predictions by this mechanism are dependent on a new high temperature vinyl oxidation route,

$$
\mathrm{C}_{2} \mathrm{H}_{3}+\mathrm{O}_{2}=\mathrm{CH}_{2} \mathrm{CHO}+\mathrm{O}
$$

with a $\mathrm{k}_{2} 2 \mathrm{H} 3+\mathrm{O} 2=\mathrm{CH} 2 \mathrm{CHO}+\mathrm{O} / \mathrm{kC} 2 \mathrm{H} 3+\mathrm{O} 2=\mathrm{CH} 2 \mathrm{O}+\mathrm{HCO}$ branching ratio of 1.20 at $1053 \mathrm{~K}$ to 2.05 at $1253 \mathrm{~K}$. The branching ratio values were dependent upon the extent of fall-off for the $\mathrm{C}_{2} \mathrm{H}_{3}+\mathrm{O}_{2}=\mathrm{CH}_{2} \mathrm{O}+\mathrm{HCO}$ reaction. 


\section{INTRODUCTION}

Ethylene is an important intermediate in the combustion of methane [4,5], larger aliphatic hydrocarbons [6,7], and aromatics [8]. Consequently, its oxidation is considered to be one of the principal submechanisms for the development of chemical kinetic models for complex fuels. We have identified nine studies devoted to the modeling of ethylene oxidation [2,9-16]. Experimental data used to validate these models were obtained from flow, static and jet-stirred reactors and from shock tubes and flames. The experimental results used for the comparison to modeling were obtained by Thornton [1] using a wellstirred reactor operated at atmospheric pressure, for temperatures of $1003 \mathrm{~K}$ to $1253 \mathrm{~K}$ and ethylene-oxygen equivalence ratios of 0.086 to 0.103 . Initial modeling of these results was reported by Westbrook et al. [2] and includes Thornton's complete data set.

That work reported that $\mathrm{H}$-atom abstraction from ethylene by $\mathrm{OH}$ attack dominated fuel consumption. The rate expression due to Tully [17] represented this primary oxidation pathway and reproduced the wellstirred reactor experimental observations for the loss of ethylene only around $1180 \mathrm{~K}$. However, the experimental results at other temperatures were not well simulated by the model, nor were the measured intermediate species well simulated.

In the present study, reported chemical kinetic mechanisms of Westbrook/Pitz (WP) [2], and Dagaut/Cathonnet/Boettner (DCB) [3] were examined, by comparing predicted species concentrations versus temperature against the measurements of Thornton. This process served as the starting point for the development of a new ethylene oxidation mechanism. Sensitivity and reaction pathway analysis were used to identify of the important reactions controlling the ethylene oxidation process and intermediate concentrations formed. Differences in the predictions amongst the mechanisms were determined in terms of the reaction pathways and/or rate expressions used. After a detailed examination of each reported mechanism was conducted, the new 
ethylene oxidation mechanism was developed.

EXPERIMENTAL - DATA SOURCE

The data of Thornton [1] were obtained using a well-stirred reactor operated with a hot gas inlet jet. The details of the well-stirred reactor have been published previously $[18,19]$, including verification of the well-stirred behavior for temperatures less than 1300K. The stirred reactor was operated at one atmosphere pressure, temperatures between $1003 \mathrm{~K}$ to $1253 \mathrm{~K}$, a nominal residence time of $2 \mathrm{msec}$, and ethyleneoxygen equivalence ratios of 0.086 to 0.103 . The products of fuel-lean hydrogen combustion of approximately $11 \% \mathrm{O}_{2}, 14 \% \mathrm{H}_{2} \mathrm{O}$, and $75 \% \mathrm{~N}_{2}$ together with the amount of ethylene $(\sim 0.36 \%)$ seeded into the jet prior to entering the stirred reactor constituted the inlet composition. All values are molar.

Gas sampling of the reactor contents was performed using an aerodynamic quench water cooled quartz probe operated at 75Torr internal pressure. Gas analysis was conducted by an on-line gas chromatography technique [1]. Detailed multipoint calibration curves were generated for $\mathrm{H}_{2}, \mathrm{CO}, \mathrm{CO}_{2}, \mathrm{O}_{2}$, and $\mathrm{C}_{2} \mathrm{H}_{4}$, since there was concern about the accuracy over the range of concentrations seen in the experiments. Only in rare cases was the accuracy of the concentration measurements poorer than that of the calibration standards of $2 \%$. Uncertainties in the measured species concentration determined by Thomton were $2 \%$ for $\mathrm{CH}_{4}$ and $\mathrm{C}_{2} \mathrm{H}_{6} ; 10 \%$ for $\mathrm{C}_{2} \mathrm{H}_{2}$; and $20 \%$ for $\mathrm{CH}_{2} \mathrm{O}$ and $\mathrm{CH}_{3} \mathrm{OH}$. No measurements were undertaken for free radicals. Errors introduced by jet-stirred reactor inhomogeneity are considered, and were estimated to be $40 \%$ for $\mathrm{CH}_{2} \mathrm{O}$ and $\mathrm{CH}_{3} \mathrm{OH}$, and $20 \%$ for the other species. Elemental carbon and oxygen balances were conducted at all temperatures and were found good to within $101 \pm 1.0 \%$ and $102 \pm 1.6 \%$. respectively. 
Non-catalytic coated type $R$ platinum-rhodium thermocouples were used to measure the reactor temperature. Uncertainties from radiation and conduction losses were estimated by Thornton to be less than $20 \mathrm{~K}$.

\section{COMPUTATIONAL MODEL AND MECHANISMS}

The computational model used for this study is the Sandia micromixed perfectly stirred reactor (PSR) code [20]. The model considers the $15.8 \mathrm{cc}$ reactor volume in which the experiments took place. Input parameters are the measured reactor temperature, inlet mass flow rate, and inlet composition.

The reported mechanisms considered in this study are summarized below:

1. The mechanism of Westbrook and Pitz (WP) was initially developed to analyze the experimental results of ethylene oxidation by Thornton [2]. Reexamination of their mechanism has been conducted for the purposes of identifying which reactions cause agreement or disagreement between the experimental data and the predictions. Both forward and reverse rates are given in the mechanism, thus insuring use of their thermochemistry.

2. The Dagaut, Cathonnet and Boettner (DCB) mechanism is an improved version of previous ethylene reaction sets reported by the group $[15,16]$. The DCB mechanism has been validated for ethylene, methane and ethane combustion for the conditions of 1-10 atmospheres, 900-1200K temperature range and fuel-air equivalence ratio range 0.1-1.5. Included in this mechanism are sixteen unimolecular and bimolecular chemically activated reactions, which have been pressure corrected to one atmosphere. Only the forward rate expressions are cited. The thermochemical data are taken from the Chemkin Thermodynamics Database [21] and Burcat thermochemical data (for $\mathrm{C}_{2} \mathrm{H}_{4} \mathrm{O}$ ) [22]. 
RESULTS OF THE REPORTED MECHANISMS

Concentration profiles for the measured stable species $\left(\mathrm{C}_{2} \mathrm{H}_{4}, \mathrm{CO}, \mathrm{CO}_{2}\right.$, $\mathrm{H}_{2}, \mathrm{CH}_{2} \mathrm{O}, \mathrm{C}_{2} \mathrm{H}_{2}, \mathrm{CH}_{3} \mathrm{OH}, \mathrm{CH}_{4}$, and $\mathrm{C}_{2} \mathrm{H}_{6}$ ) have been computed using the WP and DCB mechanisms and compared with the Thornton data set. The full presentation of the numerical computations is found and discussed in Marinov [23].

The WP and DCB mechanisms show good prediction of the loss of ethylene over limited temperature ranges. The WP mechanism well represented the loss of ethylene only around $1180 \mathrm{~K}$. The DCB mechanism shows good agreement over the $1050 \mathrm{~K}-1180 \mathrm{~K}$ range. The predicted profiles by WP and DCB along with the Thornton measurement for ethylene are represented in Figure 1. Reaction pathway analysis indicates that approximately $40 \%-50 \%$ of the ethylene is consumed by $\mathrm{OH}$ radicals followed by a substantial secondary amount of consumption by $\mathrm{O}$-atom attack. In contrast, alkyne flame modeling studies [24] found oxidation by $\mathrm{O}$-atom to be critical in fuel-lean to fuel-rich lightly sooting flames; while in alkane flames, oxidation by $\mathrm{OH}$ and $\mathrm{H}$-atom at fuel-lean to stoichiometric conditions were considered to be important.

For temperatures greater than $1180 \mathrm{~K}$, the loss of ethylene is overpredicted by both mechanisms. For temperatures above $1260 \mathrm{~K}$, concentration gradients begin to appear in the reactor [1]; that is, the rate of oxidation is no longer slow compared to the rate of mixing. Therefore, it is suspected that the difference between the measurement and prediction in this regime may be due to the effect of finite rate mixing. 


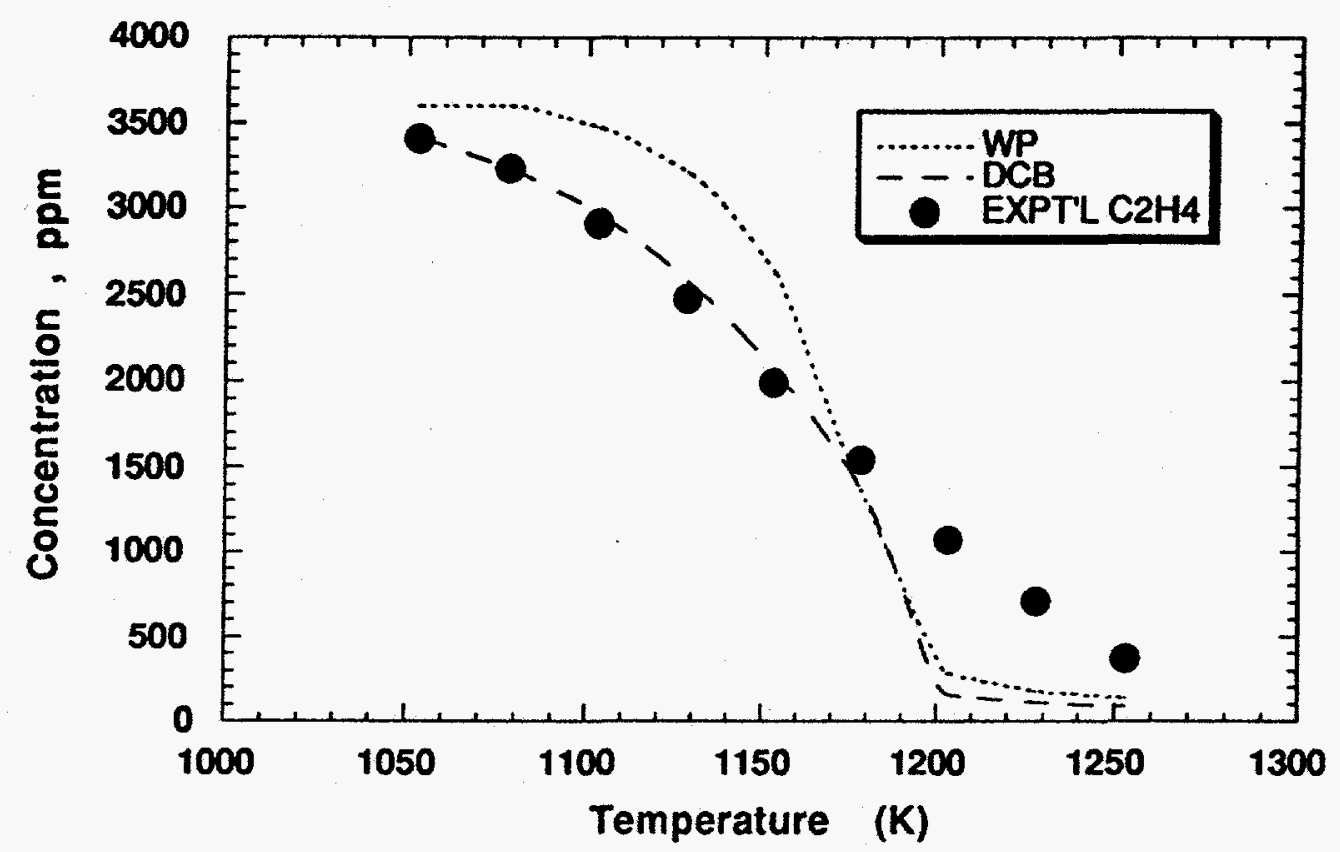

Figure 1 : Comparison of predicted and experimental concentration profile of the ethylene. Experimental (solid symbols) from Thornton [1]; Predicted curves from the mechanisms of Westbrook and Pitz (WP); and Dagaut, Cathonnet, and Boettner (DCB).

Intermediate species, in general, are not well simulated by the WP mechanism. On the other hand, the DCB mechanism simulated all stable intermediate species, except for acetylene and methanol, well for temperatures of $1050 \mathrm{~K}$ to $1180 \mathrm{~K}$. Both mechanisms overpredict acetylene by a factor of 20 to 30 , while DCB underpredicts methanol by approximately a factor of 10 . Figure 2 shows the measured and predicted profiles for acetylene and methanol. The overprediction of the acetylene profile will be discussed later. Differences exhibited by both mechanisms with regards to the predicted methanol profiles are most likely due to a lack of methyl radical production (which leads to methanol formation) or inconsistencies within the methyl radical removal kinetics. 


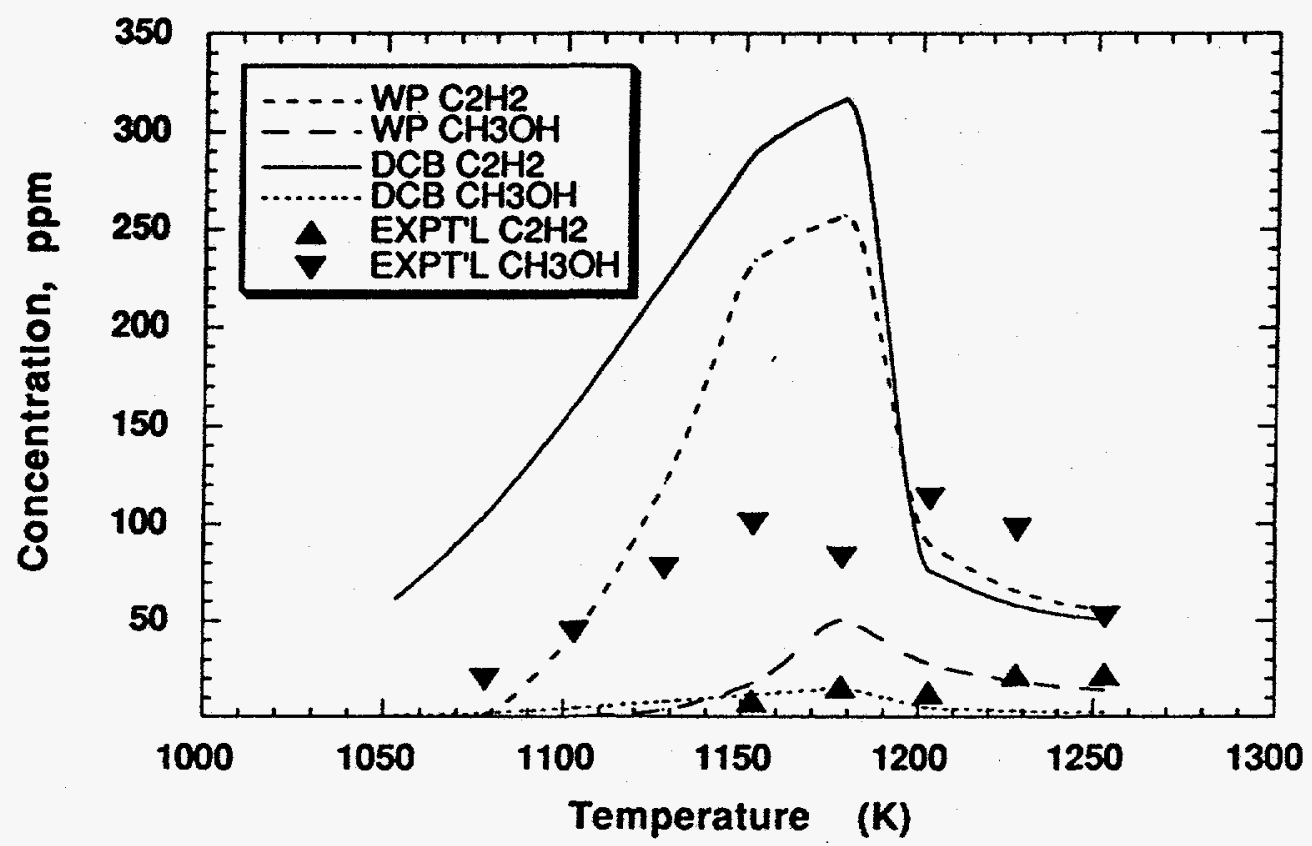

Figure 2: Comparison of predicted and experimental concentration profiles of acetylene and methanol. Experimental (solid symbols) from Thornton [1]; predicted curves from the mechanisms of Westbrook and Pitz (WP); and Dagaut, Cathonnet, and Boettner (DCB).

The WP and DCB mechanisms predict formaldehyde to within a factor of two for all temperatures. Methane, hydrogen, carbon monoxide and carbon dioxide species are well simulated by DCB for temperatures of $1050 \mathrm{~K}$ to $1180 \mathrm{~K}$, whereas the WP mechanism simulated these species well only at $1180 \mathrm{~K}$. The DCB mechanism overpredicts ethane by a factor of two to three for the $1050 \mathrm{~K}$ - $1180 \mathrm{~K}$ temperature range, while in the WP mechanism, ethane is underpredicted by roughly one order of magnitude.

A principal difference between the DCB and WP mechanisms lies in the kinetic rate of the vinyl decomposition reaction. The DCB mechanism uses a two orders of magnitude faster vinyl decomposition 
rate than the WP mechanism. The higher vinyl decomposition rate required by the DCB mechanism allows for better agreement of the ethylene profile and several intermediate species but results in poorer agreement with the acetylene profile than indicated by the WP mechanism. Reaction pathway analysis applied to the DCB mechanism indicates the vinyl decomposition reaction predominates $(>99 \%)$ over vinyl removal by $\mathrm{O}_{2}$. While in the WP mechanism, approximately $25 \%$ of the vinyl was removed by $\mathrm{O}_{2}$ with the remainder due to vinyl decomposition. The early production of $\mathrm{H}$-atom from $\mathrm{C}_{2} \mathrm{H}_{3}(+\mathrm{M})=\mathrm{C}_{2} \mathrm{H}_{2}+$ $\mathrm{H}(+\mathrm{M})$ allows for rapid chain branching through $\mathrm{H}+\mathrm{O}_{2}=\mathrm{OH}+\mathrm{O}$. The resultant $\mathrm{O}$-atom preferentially reacts with $\mathrm{C}_{2} \mathrm{H}_{4}$ producing $\mathrm{CH}_{3}+\mathrm{HCO}$ and $\mathrm{CH}_{2}+\mathrm{HCO}+\mathrm{H}$ in the $\mathrm{DCB}$ mechanism or $\mathrm{CH}_{3} \mathrm{CO}+\mathrm{H}$ in the WP mechanism. The $\mathrm{H}$-atom produced from $\mathrm{C}_{2} \mathrm{H}_{4}+\mathrm{O}$ allows for chain branching which leads to further consumption of the ethylene. The DCB mechanism attains better agreement with the experimental data in the $1050 \mathrm{~K}$ to $1180 \mathrm{~K}$ temperature range than the WP mechanism primarily due to the usage of a higher vinyl decomposition rate.

The vinyl radical has an integral role in ethylene oxidation due to the importance of the reaction $\mathrm{C}_{2} \mathrm{H}_{4}+\mathrm{OH}=\mathrm{C}_{2} \mathrm{H}_{3}+\mathrm{H}_{2} \mathrm{O}$. The DCB and WP mechanisms required the principal vinyl removal reaction to be vinyl decomposition. In order to understand the vinyl decomposition rates chosen by DCB and WP, a review was conducted on the vinyl radical decomposition reaction and vinyl radical thermochemistry.

\section{VINYL DECOMPOSITION KINETICS AND THERMOCHEMISTRY}

Table 1 gives a listing of derived rate expressions for the vinyl decomposition reaction from various reviews, recommendations and measurements. Also, a considerable range of values for the vinyl radical heat of formation is shown in Table 1 . The wide range of chemical kinetic rates and heat of formation values is indicative of the poor understanding of the vinyl radical and its decomposition process. 
Table 1

Vinyl Radical Decomposition Rate Expressions and

Vinyl Radical Heat of Formation

Rate data in $\mathrm{cm}^{3}$-mole-sec-kcal units

$$
k=A * T^{n *} \exp \left(-E_{A} / R T\right)
$$

\begin{tabular}{|c|c|c|c|c|c|}
\hline Source & $\log \mathrm{A}$ & $\mathrm{n}$ & $\mathrm{E}_{\mathrm{A}}$ & $\log \mathrm{k}(1153 \mathrm{~K})$ & Ref. \\
\hline $\mathrm{C}_{2} \mathrm{H}_{3}(+\mathrm{M})=\mathrm{C}_{2} \mathrm{H}_{2}+\mathrm{H}(+\mathrm{M})$ & $\mathrm{a}) \mathrm{b}) \mathrm{d})$ & & & \\
\hline DC B & 44.323 & -8.447 & 51.106 & 8.77 & 3 \\
WP & 28.58 & -4.4 & 44.29 & 6.71 & 2 \\
Tsang/Hampson & 44.715 & -9.8 & 52.24 & 4.81 & 4 \\
B aulch & 42.352 & -9.2 & 49.14 & 4.87 & 25 \\
Warnatz & 13.567 & -1.0 & 32.06 & 4.43 & 5 \\
Miller / Bowman & 25.639 & -4.4 & 42.52 & 4.11 & 26 \\
KWKWc) & $36.79 \pm 0.4$ & -8.17 & 45.59 & 3.13 & 27 \\
Rao/Skinner $)$ & 13.73 & -1.3 & 33.97 & 3.31 & 28.5 \\
Source & $\Delta \mathrm{H}_{\mathrm{f}}\left(298 \mathrm{~K}, \mathrm{C}_{2} \mathrm{H}_{3}\right)$ & $\mathrm{Ref}$ & & \\
Ayranci / Back & 63.4 & $\mathrm{kcal} / \mathrm{mol}$ & 29 & & \\
Lossing & 59.6 & 30 & & \\
Shiromaru & 77 & 31 & & \\
Golden & 66 & 28 & & \\
McMillian / Golden & 70.4 & 32 & & \\
Kee et al. & 68.4 & 21 & & \\
Devrees et al. & 71.5 & 33 & & \\
Sharma et al. & 72 & 34 & & \\
Ervin et al. & 71.7 & 35 & & \\
\hline
\end{tabular}

a) Corrected for fall-off at $1.0 \mathrm{~atm}$. b) Based on $\Delta \mathrm{H}_{\mathrm{f}}\left(\mathrm{C}_{2} \mathrm{H}_{3}, 298 \mathrm{~K}\right)=68.4 \mathrm{kcal} / \mathrm{mol}$ c) KWKW performed RRKM calculations based on $\Delta \mathrm{H}_{f}\left(\mathrm{C}_{2} \mathrm{H}_{3}, 298 \mathrm{~K}\right)=63.4 \mathrm{kcal} / \mathrm{mol}$. This study has adjusted the activation energy downward from $50.59 \mathrm{kcal} / \mathrm{mol}$ to $45.59 \mathrm{kcal} / \mathrm{mol}$ to obtain a comparison to other rate expression evaluations performed at $\Delta \mathrm{H}_{\mathrm{f}}\left(\mathrm{C}_{2} \mathrm{H}_{3}, 298 \mathrm{~K}\right)=68.4 \mathrm{kcal} / \mathrm{mol}$.

d) Rate expression units: $\mathrm{sec}^{-1}$

e) Used $\mathrm{k}_{\infty}, \mathrm{C} 2 \mathrm{H} 2+\mathrm{H}=\mathrm{C} 2 \mathrm{H} 3$ from Warnatz [5] for Lindemann-Hinshelwood pressure correction. Equilibrium constants calculated from Kee et al. thermochemistry [21].

\section{Vinyl Radical Heat of Formation}

The choice of the heat of formation value used may have an impact on the modeling calculations. Thermodynamic considerations point out that a higher heat of formation value implies less stability of the vinyl radical which in turn favors higher net destruction rates for vinyl decomposition or oxidation reactions. However, in the current study, no sensitivity analysis was conducted to assess the best heat of formation 
value. Current measurements $[33-35]$ indicate that the vinyl radical heat of formation should be $71.8 \pm 0.3 \mathrm{kcal} / \mathrm{mol}$.

\section{Vinyl Decomposition}

The compiled list of $\mathrm{C}_{2} \mathrm{H}_{3}(+\mathrm{M})=\mathrm{C}_{2} \mathrm{H}_{2}+\mathrm{H}(+\mathrm{M})$ rate expressions, presented in Table 1, are plotted figure 3. These expressions have been derived and corrected for fall-off. The list includes the reviews by Tsang and Hampson [4], Baulch et al. [25], and Warnatz [5], plus the recommendation from Miller and Bowman [26]. Recent shock tube studies of Kiefer, Wei, Kern and Wu (KWKW) [27], and Rao and Skinner [28] have been included.

Pressure correction is performed according to the information presented by the various evaluations, and is based on a $68.4 \mathrm{kcal} / \mathrm{mol}$ heat of formation value. Tsang and Hampson obtained an RRKM calculated low pressure rate expression based on the forward rate expression determined by Benson and Haugen [36], plus the measured low temperature and high pressure reverse rates of Payne and Stief [37] and Sugarawa et al. [38]. The Tsang and Hampson low pressure rate expression was corrected for weak collisions by using the recommended collisional deactivation step size of $450 \mathrm{~cm}^{-1}$ for an $\mathrm{N}_{2}$ collider at one atmosphere. Baulch et al. [25] recommended the use of the Tsang and Hampson vinyl decomposition low pressure rate expression but advised the use of the Troe Method for fall-off corrections. The high pressure forward rate expression was taken from the Warnatz [5] review; and a center-broadening parameter value of 0.35 as recommended by Baulch et al. was then used to derive the Table 1 expression. The Warnatz [5] recommended low and high pressure forward rate expressions are based 


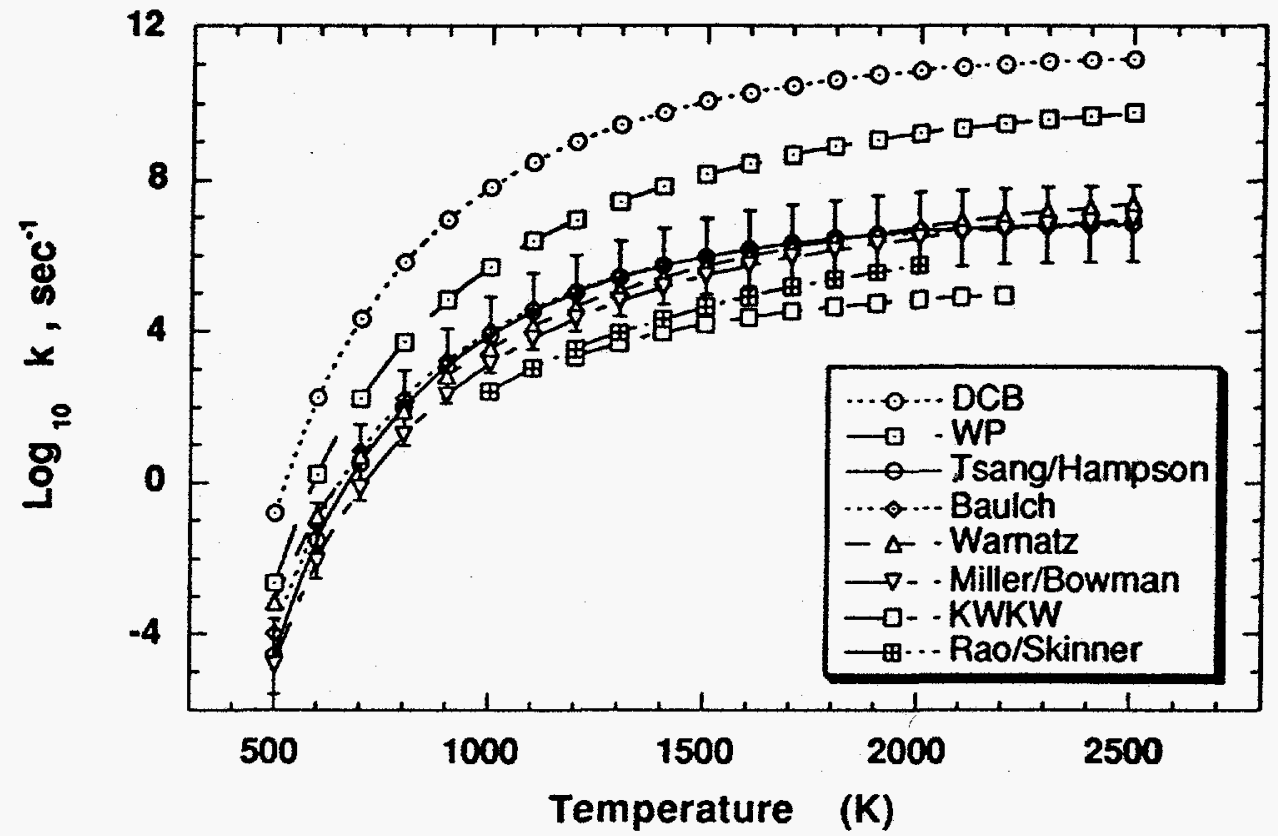

Figure 3: Evaluated kinetic rate data at one atmosphere for vinyl decomposition based on $\Delta \mathrm{H}_{\mathrm{f}}\left(\mathrm{C}_{2} \mathrm{H}_{3}, 298 \mathrm{~K}\right)=68.4 \mathrm{kcal} / \mathrm{mol}$. See Table 1 for the numerical representation of the fall-off corrected kinetic rates.

on literature data taken from the 1960's and 1970's. The LindemannHinshelwood method was then applied to derive the rate expression ascribed to Warnatz in Table 1 . All of the rate expressions from the various reviews, along with the Miller and Bowman recommendation, have an uncertainty factor of 10 . This is noted by the bars placed about the Tsang and Hampson rate expression. Clearly, all reviews are in accordance with one another.

Recent shock tube measurements indicate slower vinyl decomposition kinetics than suggested by the reviews. The high temperature vinyl-bromide and vinyl-iodide pyrolysis shock tube measurements of Rao and Skinner [28] indicate that the vinyl decomposition rate occurs a factor of 10 slower than given by the 
reviews. Their vinyl decomposition results were determined independently of the vinyl radical heat of formation and support the revised rate expression of $\mathrm{KWKW}$ [27] as determined by the present study. The high temperature 1,3-butadiene pyrolysis shock tube measurements and RRKM analysis of KWKW suggest a relatively stable vinyl radical and a slow vinyl decomposition rate.

The WP and DCB mechanisms utilize vinyl decomposition kinetic rates which exceed the upper uncertainty factor limit for the reviewed evaluations by approximately one and three orders of magnitude. Furthermore, the WP and DCB mechanism's usage of fast vinyl decomposition rates is not supported by the Rao/Skinner and KWKW shock tube studies. The analysis of the vinyl decomposition process coupled with the poor acetylene modeling predictions of DCB and WP clearly suggest that a lower vinyl decomposition rate must be used.

However, we must recall that good agreement by the DCB and WP model predictions with the Thornton data set was predicated by the requirement of a high $\mathrm{C}_{2} \mathrm{H}_{3}(+\mathrm{M}) \rightarrow \mathrm{C}_{2} \mathrm{H}_{2}+\mathrm{H}(+\mathrm{M})$ rate which sustained rapid chain branching through $\mathrm{H}+\mathrm{O}_{2}=\mathrm{OH}+\mathrm{O}$. These results imply that the early free radical production path must come from vinyl oxidation by $\mathrm{O}_{2}$ and not from vinyl decomposition. A review of the $\mathrm{C}_{2} \mathrm{H}_{3}$ plus $\mathrm{O}_{2}$ chemistry was conducted in order to examine the potential product pathways of this reactant pairing.

\section{VINYL OXIDATION KINETICS}

Table 2 represents a listing of the assigned products and rate expressions involving the important vinyl oxidation reactions. A wide range of rates are exhibited for the $\mathrm{C}_{2} \mathrm{H}_{3}+\mathrm{O}_{2}$ pathways to $\mathrm{CH}_{2} \mathrm{O}+\mathrm{HCO}$, $\mathrm{C}_{2} \mathrm{H}_{2}+\mathrm{HO}_{2}$ and $\mathrm{CH}_{2} \mathrm{CHO}+\mathrm{O}$-atom. This is due to the uncertainty in the $\mathrm{C}_{2} \mathrm{H}_{3}+\mathrm{O}_{2}$ product domination at typical combustion temperatures (i.e. $\mathrm{T}>$ 900K). 
Table 2

Vinyl Radical Oxidation Reaction Rate Expressions

Rate Data in $\mathrm{cm}^{3}$-mole-sec-kcal units

$k=A * T^{n *} \exp \left(-E_{A} / R T\right)$

\begin{tabular}{|c|c|c|c|c|c|}
\hline Source & $\log A$ & $\mathbf{n}$ & $\mathbf{E}_{\mathbf{A}}$ & $\log k(1153 K)$ & Ref. \\
\hline \multicolumn{6}{|c|}{$\left.\mathrm{C}_{2} \mathrm{H}_{3}+\mathrm{O}_{2}=\mathrm{CH}_{2} \mathrm{O}+\mathrm{HCO}^{\mathrm{a}} \mathrm{c}\right)$} \\
\hline $\begin{array}{c}\text { Gutman et al. } \\
\text { DC B } \\
\text { WP } \\
\text { Westmoreland } \\
\text { Bozzelli/Dean } \\
\text { b) }\end{array}$ & $\begin{array}{c}12.60 \\
12.48 \\
12.176 \\
26.651 \\
23.037\end{array}$ & $\begin{array}{l}0.0 \\
0.0 \\
0.0 \\
-4.55 \\
-3.29\end{array}$ & $\begin{array}{c}-0.248 \\
-0.25 \\
0.0 \\
5.48 \\
3.892\end{array}$ & $\begin{array}{l}12.647 \\
12.527 \\
12.176 \\
11.681 \\
12.226\end{array}$ & $\begin{array}{c}39 \\
3 \\
2 \\
40 \\
41\end{array}$ \\
\hline \multicolumn{6}{|c|}{$\left.\mathrm{C}_{2} \mathrm{H}_{3}+\mathrm{O}_{2}=\mathrm{C}_{2} \mathrm{H}_{2}+\mathrm{HO}_{2}{ }^{\mathrm{a}) \mathrm{c}}\right)$} \\
\hline $\begin{array}{c}\text { Tsang/Hampson } \\
\text { Glarborg } \\
\text { Warnatz }\end{array}$ & $\begin{array}{l}11.08 \\
12.73 \\
12.0\end{array}$ & $\begin{array}{l}0.0 \\
0.0 \\
0.0\end{array}$ & $\begin{array}{l}0.0 \\
0.0 \\
0.0\end{array}$ & $\begin{array}{l}11.08 \\
12.73 \\
12.0\end{array}$ & $\begin{array}{c}4 \\
42 \\
5\end{array}$ \\
\hline $\begin{array}{l}\text { Westmoreland } \mathbf{b}) \\
\text { addition rxn. } \\
\text { Westmoreland }\end{array}$ & 21.708 & -3.24 & 5.66 & 10.72 & 40 \\
\hline metathesis rxn. & 11.6 & 0.0 & 0.0 & 11.6 & 40 \\
\hline $\begin{array}{l}\text { Bozzelli/Dean } b) \\
\text { DCB and WP did } \\
\mathrm{C}_{2} \mathrm{H}_{3}+\mathrm{O}_{2}=\mathrm{CH}_{2}\end{array}$ & $\begin{array}{c}15.715 \\
\text { include } \\
\left(\mathrm{O}+\mathrm{O}^{\mathrm{a})} \mathrm{c}\right)\end{array}$ & $\begin{array}{l}-1.26 \\
\text { reaction }\end{array}$ & 3.31 & 11.23 & 41 \\
\hline $\begin{array}{l}\text { Westmoreland } \\
\text { Bozzelli/Dean }\end{array}$ & $\begin{array}{l}12.279 \\
15.391\end{array}$ & $\begin{array}{l}-0.65 \\
-0.78\end{array}$ & $\begin{array}{c}5.77 \\
3.135\end{array}$ & $\begin{array}{c}9.195 \\
12.408\end{array}$ & $\begin{array}{l}40 \\
41\end{array}$ \\
\hline
\end{tabular}

a) Corrected for fall-off at $1.0 \mathrm{~atm}, \mathrm{M}=\mathrm{N}_{2}$.

b) Based on $\Delta \mathrm{H}_{\mathrm{f}}\left(\mathrm{C}_{2} \mathrm{H}_{3}, 298 \mathrm{~K}\right)=70.4 \mathrm{kcal} / \mathrm{mol}$

c) Rate expression units: $\mathrm{cm}^{3} / \mathrm{mol}-\mathrm{sec}$

Vinyl Oxidation "by Molecular Oxygen

The dearth of high temperature studies concerning the reaction kinetics of $\mathrm{C}_{2} \mathrm{H}_{3}+\mathrm{O}_{2}$ is the primary cause of uncertainty in product formation and rates at combustion conditions. However, the kinetics are well-defined at low temperatures. Experiments by Baldwin and Walker [43] and Gutman et al. $[39,44]$ indicated that the $\mathrm{C}_{2} \mathrm{H}_{3}+\mathrm{O}_{2}$ addition channel leading to $\mathrm{CH}_{2} \mathrm{O}+\mathrm{HCO}$ is the primary products at low temperatures. Gutman et al. measured rate constants and conclusively 
established that $\mathrm{C}_{2} \mathrm{H}_{3}+\mathrm{O}_{2}$ formed $\mathrm{CH}_{2} \mathrm{O}+\mathrm{HCO}$ at 297-599K and 0.48-3.6 torr He. No $\mathrm{C}_{2} \mathrm{H}_{2}$ and $\mathrm{HO}_{2}$ were detected, so any $\mathrm{C}_{2} \mathrm{H}_{2}+\mathrm{HO}_{2}$ product pathway contribution is considered to be less than $10 \%$.

No direct high temperature chemical kinetic studies have been conducted to examine the $\mathrm{C}_{2} \mathrm{H}_{3}+\mathrm{O}_{2}$ reaction. Recently, Chevalier (as cited by Just [45]) modeled laminar flame speeds for ethylene flames and determined the $\mathrm{C}_{2} \mathrm{H}_{3}+\mathrm{O}_{2}=\mathrm{C}_{2} \mathrm{H}_{2}+\mathrm{HO}_{2}$ reaction to be important.

Reviews by Tsang and Hampson [4] and Wamatz [5] assumed the $\mathrm{C}_{2} \mathrm{H}_{3}$ $+\mathrm{O}_{2}$ reaction proceeded to $\mathrm{C}_{2} \mathrm{H}_{2}+\mathrm{HO}_{2}$ in an analogous fashion to the $\mathrm{C}_{2} \mathrm{H}_{5}+\mathrm{O}_{2}$ reaction, which is thought to proceed by simple $\mathrm{H}$-atom abstraction by $\mathrm{O}_{2}$ under combustion conditions. However, the recent study by Wagner et al. [46] postulated that the $\mathrm{C}_{2} \mathrm{H}_{5}+\mathrm{O}_{2}$ reaction is complex. The reaction involves $\mathrm{O}_{2}$ addition followed by stabilization of the adduct (only for temperatures below approximately 650K) or isomerization of the adduct followed by decomposition to $\mathrm{C}_{2} \mathrm{H}_{4}+\mathrm{HO}_{2}$. The postulated reaction scheme effectively rules out the direct $\mathbf{H}$-atom metathesis route for $\mathrm{C}_{2} \mathrm{H}_{5}+\mathrm{O}_{2}$, and therefore suggests that $\mathrm{H}$-atom abstraction from $\mathrm{C}_{2} \mathrm{H}_{3}$ by $\mathrm{O}_{2}$ is unlikely to occur. Interestingly, Westmoreland [40] suggested the possibility that $\mathrm{C}_{2} \mathrm{H}_{3}+\mathrm{O}_{2}$ metathesis to $\mathrm{C}_{2} \mathrm{H}_{2}+\mathrm{HO}_{2}$ products could dominate at temperatures above $1500 \mathrm{~K}$ depending on the nature of the fall-off for the $\mathrm{C}_{2} \mathrm{H}_{3}+\mathrm{O}_{2}=\mathrm{CH}_{2} \mathrm{O}+\mathrm{HCO}$ reaction.

Recently, Westmoreland [40] and Bozzelli/Dean [41] independently performed theoretical calculations using the Bimolecular-QRRK method to the $\mathrm{C}_{2} \mathrm{H}_{3}+\mathrm{O}_{2}$ reaction system. Westmoreland determined that the prinicipal $\mathrm{C}_{2} \mathrm{H}_{3}+\mathrm{O}_{2}$ product channel is $\mathrm{CH}_{2} \mathrm{O}+\mathrm{HCO}$ at all conditions, however, he suggested the possibility of $\mathrm{C}_{2} \mathrm{H}_{2}+\mathrm{HO}_{2}$ products dominating at high temperatures if the $\mathrm{C}_{2} \mathrm{H}_{3}+\mathrm{O}_{2}$ metathesis reaction exists. This result differs from Bozzelli and Dean who claim that the vinoxy (i.e. the carbon centered radical $\mathrm{CH}_{2} \mathrm{CHO}$ ) + O-atom channel dominates at high temperatures and the $\mathrm{CH}_{2} \mathrm{O}+\mathrm{HCO}$ product channel dominates at low to intermediate temperatures. The $\mathrm{C}_{2} \mathrm{H}_{2}+\mathrm{HO}_{2}$ product channel was 
determined to be unimportant by the Bozzelli/Dean study.

The theoretically calculated rate expressions for the $\mathrm{C}_{2} \mathrm{H}_{3}+\mathrm{O}_{2}=$ $\mathrm{CH}_{2} \mathrm{CHO}+\mathrm{O}$ reaction channel between the Westmoreland and Bozzelli/Dean studies differ by more than three orders of magnitude. An explanation for the large difference between the Westmoreland and the Bozzelli/Dean predictions lies in the input parameters chosen for the Bimolecular-QRRK analysis. In particular, the input parameters for the high pressure pre-exponential frequency factor in the forward direction, $A_{\infty}$, fwd, and the high pressure activation energy barrier in the forward direction, $E_{a c t, \infty}$, fwd, needed to describe the kinetics of the reaction $\mathrm{C}_{2} \mathrm{H}_{3} \mathrm{OO} \leftrightarrow \mathrm{CH}_{2} \mathrm{CHO}+\mathrm{O}$ (after $\mathrm{O}_{2}$ addition to the vinyl radical). Westmoreland assumed a tight transition state structure for the $\mathrm{O}$-atom addition to the oxygen of the carbonyl bond (i.e. $\mathrm{C}=\mathrm{O}$ ) in $\mathrm{CH}_{2} \mathrm{CHO}$. He calculated a $A_{\infty}, \mathrm{rev}$ of $2 \times 10^{10} \mathrm{~cm}^{3} \mathrm{~mol}^{-1} \mathrm{sec}^{-1}$ with microscopic reversibility yielding $A_{\infty}, \mathrm{fwd}=2.1 \times 10^{12} \mathrm{~cm}^{3} \mathrm{~mol}^{-1} \mathrm{sec}^{-1}$. Bozzelli and Dean used the analogy of O-atom addition to ethylene to obtain the reverse A-factor for $\mathrm{O}$-atom addition to the oxygen of the carbonyl bond in $\mathrm{CH} 2 \mathrm{CHO}$. Their analogy yielded a $\mathrm{A}_{\infty}$, rev value of $7.8 \times 10^{12} \mathrm{~cm}^{3}$ $\mathrm{mol}^{-1} \mathrm{sec}^{-1}$ with microscopic reversibility yielding $\mathrm{A}_{\infty}, \mathrm{fwd}=3.3 \times 10^{14}$ $\mathrm{cm}^{3} \mathrm{~mol}^{-1} \mathrm{sec}^{-1}$. The three orders of magnitude difference (at this study's conditions) between the Westmoreland and Bozzelli/Dean QRRK predicted kinetics for $\mathrm{C}_{2} \mathrm{H}_{3}+\mathrm{O}_{2}=\mathrm{CH}_{2} \mathrm{CHO}+\mathrm{O}$ is primarily due to the $A_{\infty}$,rev determination. The large difference in $A_{\infty}, f w d$ (or $A_{\infty}$, rev ) indicates a problem of interpreting the structure of the chemically activated and resonantly stabilized 2-oxo-ethyl - $O$ atom/ethenyloxy - $O$ atom $\left(\mathrm{C}_{2} \mathrm{H}_{3} \mathrm{O}--\mathrm{O}\right)$ complex. There is also a $\sim 8.0 \mathrm{kcal} / \mathrm{mol}$ energy barrier difference between the two studies regarding the choice of Eact,, rev for the addition of O-atom to the oxygen of the carbonyl bond in $\mathrm{CH}_{2} \mathrm{CHO}$,

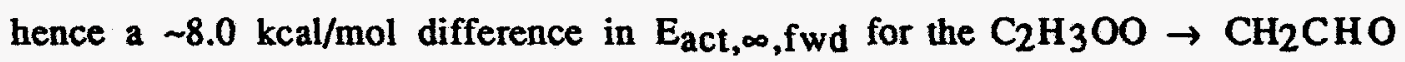
+ O-atom reaction. This energy barrier difference accounts for the remaining disagreement in the predicted kinetics for $\mathrm{C}_{2} \mathrm{H}_{3}+\mathrm{O}_{2}=$ $\mathrm{CH}_{2} \mathrm{CHO}+\mathrm{O}$ between Westmoreland and Bozzelli/Dean. The difference in barrier heights between the two studies is critical for the predicted $\mathrm{C}_{2} \mathrm{H}_{3}+\mathrm{O}_{2}=\mathrm{CH}_{2} \mathrm{CHO}+\mathrm{O}$ kinetics at low temperatures, whereupon we refer 
the reader to Bozzelli/Dean's work. The most important difference that can be concluded for high temperature combustion is the choice of the high pressure A-factor for the $\mathrm{C}_{2} \mathrm{H}_{3} \mathrm{OO} \leftrightarrow \mathrm{CH}_{2} \mathrm{CHO}+\mathrm{O}$ reaction.

If the primary oxidation channel is $\mathrm{CH}_{2} \mathrm{O}+\mathrm{HCO}$ at high temperatures, then the early source of reactive free radicals must come from formyl radical dissociation. The $\mathbf{H}$-atom produced from formyl decomposition would be sufficient to sustain chain branching and further ethylene oxidation. The other possibility, $\mathrm{C}_{2} \mathrm{H}_{2}+\mathrm{HO}_{2}$, may be ruled out due to poor predictions of the acetylene profile that would result if this reaction were to be favored and the production of an unreactive $\mathrm{HO} 2$ radical. The vinoxy plus $\mathrm{O}$-atom channel is attractive as an early $\mathrm{O}$-atom is produced, furthermore the vinoxy radical will decompose to ketene and $\mathrm{H}$-atom which will make this reaction pathway a truly chain branching process. A final point involves the possibility of vinyl plus a radical reaction. It is unlikely that such a reactant pairing will provide the necessary impetus for substantial reactive free radical production. Examination of these possible reaction sequences were examined by this study's developed ethylene oxidation model.

\section{THIS STUDY'S ETHYLENE OXIDATION MODEL}

An ethylene oxidation mechanism has been developed to reproduce the measurements of Thornton [1]. as well as the lean, atmospheric pressure, methane and ethane jet stirred reactor data sets for the $900 \mathrm{~K}$ to $1200 \mathrm{~K}$ range of Dagaut et al. [3,47]. This development is warranted by three factors:

1. The lack of agreement between the modeled concentrations based on the WP and DCB mechanisms and the Thornton data set.

2. Significantly different concentration predictions obtained by the WP and DCB mechanisms. 
3. The large rates of vinyl decomposition required by the WP and DCB mechanisms relative to the results of the recent shock tube studies (Figure 3).

The ethylene mechanism is listed in Table 3 and consists of 206 reactions and 40 species. Third body efficiencies and pressure corrections are applied as necessary. Table 4 shows the thermochemistry used with the mechanism.

\section{Ethylene Kinetics:}

For the $1053 \mathrm{~K}$ to $1253 \mathrm{~K}$ temperature range of this study, approximately $41 \%$ of the ethylene is consumed by reaction (50) of Table 3:

$$
\mathrm{C}_{2} \mathrm{H}_{4}+\mathrm{OH}=\mathrm{C}_{2} \mathrm{H}_{3}+\mathrm{H}_{2} \mathrm{O}
$$

Chemical kinetic modeling analysis favors the use of the Atkinson [56] rate expression over that of the recent study by Bott and Cohen [132] because of the favorable modeling of the overall rate of loss of the ethylene. The non-Arrhenius rate expression fit of Atkinson [59] is based on the experimental results of Tully [17] and Smith [133].

The $\mathrm{C}_{2} \mathrm{H}_{4}+\mathrm{O}$ reaction accounts for approximately $45 \%$ to $50 \%$ consumption of the ethylene in the present study. The rate expression used for the $\mathrm{C}_{2} \mathrm{H}_{4}+\mathrm{O}$ reaction is taken from Klemm et al. [60]. Their results are represented by an Arrhenius expression for the $1052 \mathrm{~K}$ $2000 \mathrm{~K}$ temperature range. The present study uses the product channels for the $\mathrm{C}_{2} \mathrm{H}_{4}+\mathrm{O}$ reaction as suggested by Dagaut et al. [16]. These are

$$
\begin{aligned}
& \mathrm{C}_{2} \mathrm{H}_{4}+\mathrm{O}=\mathrm{CH}_{3}+\mathrm{HCO} \\
& \mathrm{C}_{2} \mathrm{H}_{4}+\mathrm{O}=\mathrm{CH}_{2}+\mathrm{HCO}+\mathrm{H}
\end{aligned}
$$

A branching ratio of $k_{51} / k_{52}=2.3$ is applied in accord with Schmoltner et al. [134]. 
Table 3

Ethylene oxidation mechanism. Rate data in $\mathrm{cm}^{3}$-mole-sec-kcal units,

$$
k=A^{*} T^{n} * \exp \left(-E_{A} / R T\right)
$$

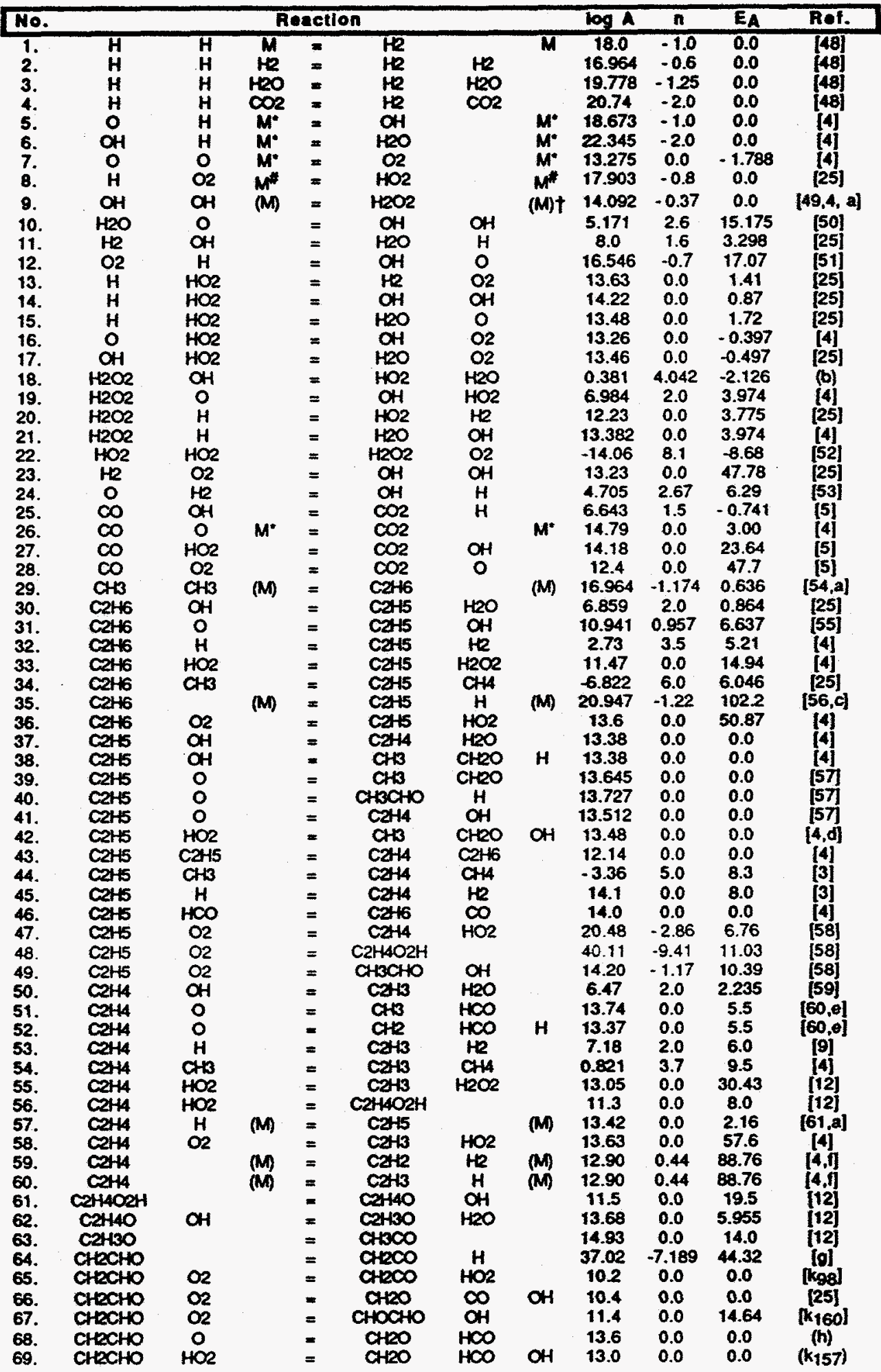




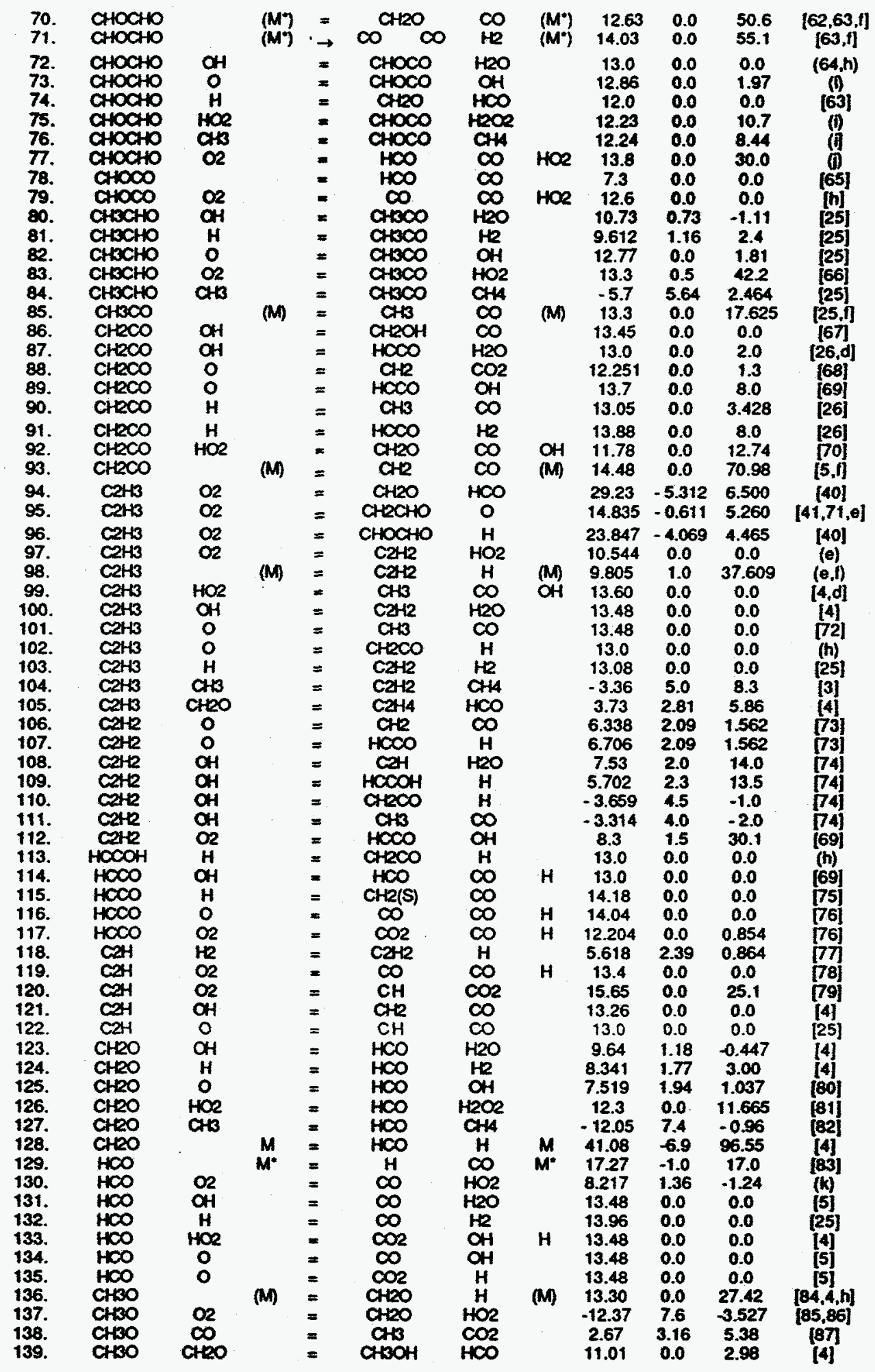




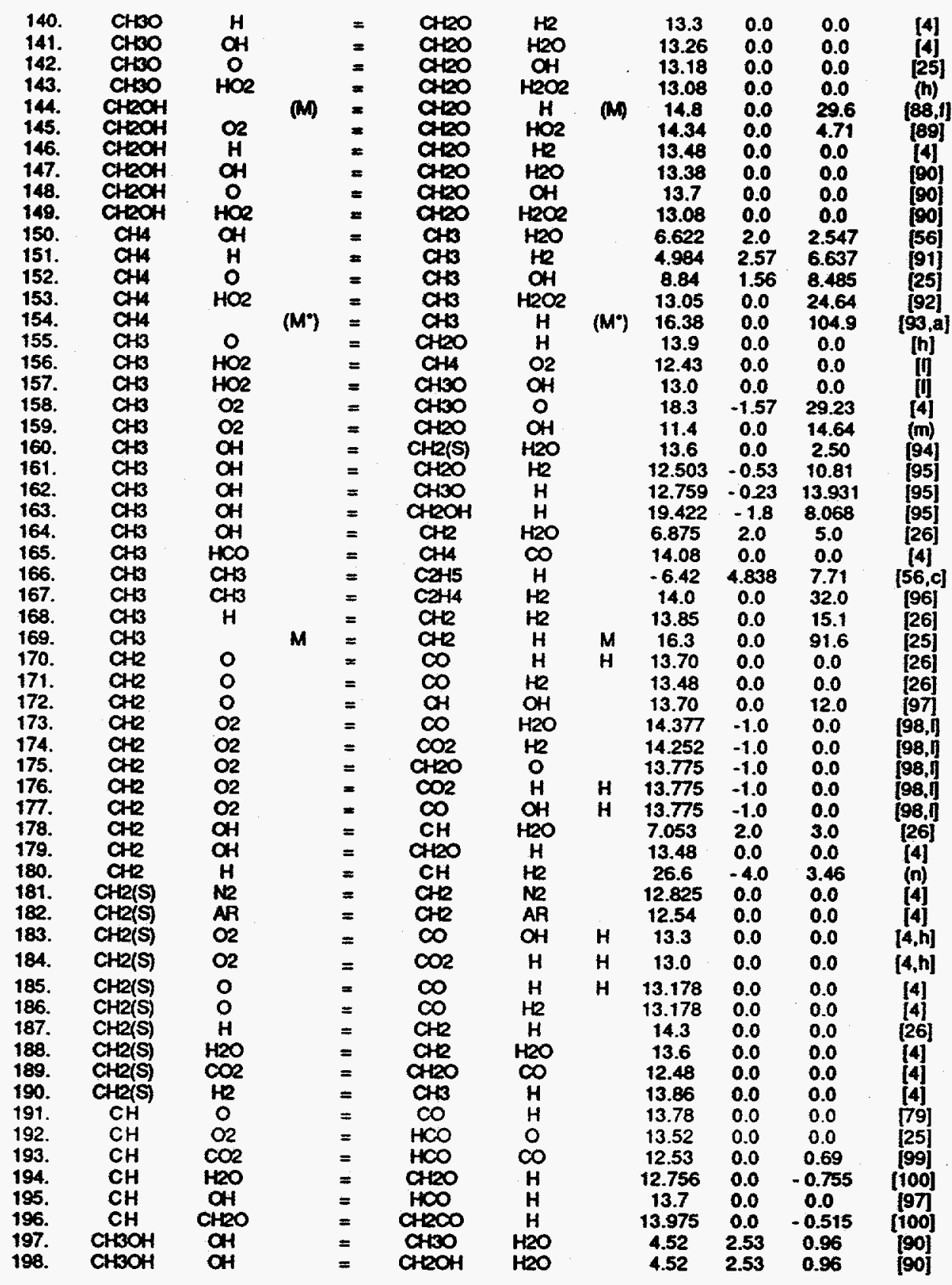




\begin{tabular}{|c|c|c|c|c|c|c|c|c|c|c|c|}
\hline $\begin{array}{l}199 . \\
200 . \\
201 . \\
202 . \\
203 . \\
204 . \\
205 . \\
206 .\end{array}$ & $\begin{array}{l}\text { CHBOH } \\
\text { CHBOH } \\
\text { CHBOH } \\
\text { CHBOH } \\
\text { CHBOH } \\
\text { CHBOH } \\
\mathrm{CH} \text { BOH } \\
\mathrm{CH} \text { (3OH }\end{array}$ & $\begin{array}{c}H \\
H \\
O \\
C H B \\
C H B \\
H O 2 \\
O 2\end{array}$ & $(M)$ & $\begin{array}{l}= \\
= \\
= \\
= \\
= \\
= \\
= \\
=\end{array}$ & 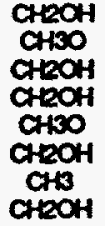 & $\begin{array}{c}H 2 \\
H 2 \\
O H \\
C H 4 \\
C H 4 \\
H 2 O 2 \\
O H \\
H O 2\end{array}$ & (M) & $\begin{array}{c}8.505 \\
6.623 \\
5.589 \\
1.5 \\
1.16 \\
13.6 \\
16.3 \\
13.31\end{array}$ & $\begin{array}{l}1.49 \\
2.11 \\
2.5 \\
3.17 \\
3.1 \\
0.0 \\
0.0 \\
0.0\end{array}$ & $\begin{array}{c}4.25 \\
4.868 \\
3.08 \\
7.17 \\
6.23 \\
19.4 \\
89.87 \\
44.91\end{array}$ & $\begin{array}{c}{[101]} \\
{[90]} \\
{[80]} \\
{[90]} \\
{[90]} \\
{[102]} \\
{[103,1,]} \\
{[80]}\end{array}$ \\
\hline
\end{tabular}

\begin{tabular}{|c|c|c|c|c|c|}
\hline No. & Fall- Off Correction Parameters & $\log A$ & $\mathbf{n}$ & $\mathbf{E}_{\mathbf{A}}$ & Ref. \\
\hline $\begin{array}{l}9 . \\
29 . \\
35\end{array}$ & 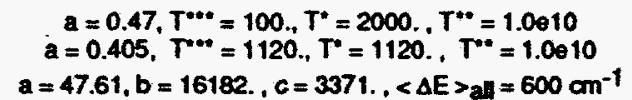 & $\begin{array}{l}30.493 \\
36.06 \\
42.84\end{array}$ & $\begin{array}{l}-4.63 \\
-5.246 \\
-6.431\end{array}$ & $\begin{array}{c}2.046 \\
1.71 \\
107.2\end{array}$ & $\begin{array}{c}{[49,4]} \\
{[54]} \\
{[56,0]}\end{array}$ \\
\hline $\begin{array}{l}57 . \\
59 . \\
60 . \\
70 . \\
71 . \\
85 . \\
93 . \\
99 . \\
136 . \\
144 . \\
154 . \\
166 .\end{array}$ & $\begin{array}{c}a=1 ., T^{* *}=1, T^{*}=786, T^{* *}=3250 . \\
a=0.638, T^{* * *}=1.00-10, T^{*}=3230 ., T^{* *}=1.0010 \\
a=1.641, b=4334, c=2725 .,<\Delta E>a 1=600 \mathrm{~cm}^{-1}\end{array}$ & $\begin{array}{l}18.6 \\
17.42 \\
17.42 \\
16.95 \\
16.41 \\
27.73 \\
15.56 \\
14.18 \\
25.37 \\
14.88 \\
17.66 \\
12.7\end{array}$ & $\begin{array}{l}0.0 \\
0.0 \\
0.0 \\
0.0 \\
0.0 \\
-3.37 \\
0.0 \\
0.1 \\
-2.7 \\
0.0 \\
0.0 \\
0.099\end{array}$ & $\begin{array}{c}1.12 \\
79.35 \\
96.56 \\
49.2 \\
38.4 \\
18.88 \\
59.27 \\
32.67 \\
30.6 \\
20.0 \\
90.81 \\
10.6\end{array}$ & $\begin{array}{c}{[61]} \\
{[5]} \\
{[5]} \\
{[63]} \\
{[63]} \\
{[25]} \\
{[5]} \\
{[27, \mathrm{c}]} \\
{[4, d, 1]} \\
{[88]} \\
{[93]} \\
{[56,0]}\end{array}$ \\
\hline 205. & - & 17.3 & 0.0 & 68.36 & {$[103]$} \\
\hline
\end{tabular}

$\left[\mathrm{M}^{H}\right]=21.0\left[\mathrm{H}_{2} \mathrm{O}\right]+3.8[\mathrm{CO}]+16.0\left[\mathrm{CH}_{4}\right]+2.5\left[\mathrm{H}_{2}\right]+1.9[\mathrm{CO}]$

$\left[\mathrm{M}^{*}\right]=16.0\left[\mathrm{H}_{2} \mathrm{O}\right]+3.8\left[\mathrm{CO}_{2}\right]+16.0\left[\mathrm{CH}_{4}\right]+2.5\left[\mathrm{H}_{2}\right]+1.9[\mathrm{CO}]$

$\left[\mathrm{M}^{* *}\right]=10.0\left[\mathrm{H}_{2} \mathrm{O}\right]+2.0\left[\mathrm{O}_{2}\right]+2.0\left[\mathrm{~N}_{2}\right]+2.0\left[\mathrm{H}_{2}\right]$

t All pressure corrected reactions have the high pressure rate expression listed in the full mechanism. The low pressure rate expression is listed below along with its associated fall - off correction parameters.

(a) Fall - off reaction in the Troe form:

$F_{\text {cent }}=(1-a) \exp \left(-T / T^{* * *}\right)+a \exp \left(-T / T^{*}\right)+\exp \left(-T^{* *} / T\right)$

(b) Fitted expression based on Ref. [104-111]

(c) Fall - off reaction in the SRI form: $F^{s c}=a \exp (-b / T)+\exp (-T / c)$

(d) Adjusted

(e) See Text

(f) Fall - off reaction in the Lindemann - Hinshelwood form.

(g) QRRK calculated rate expression at one atmosphere, $M=N_{2}$.

(h) Estimate Input parameters are available from the authors by request.

(i) Estimate based on $\mathrm{CH}_{3} \mathrm{CHO}+\mathrm{X}\left(\mathrm{X}=\mathrm{OH}, \mathrm{O}, \mathrm{HO}_{2}, \mathrm{CH}_{3}\right)$ reaction.

(j) The pre-exponential frequency factor is estimated by analogy to $\mathrm{CH}_{2} \mathrm{O}+\mathrm{O}_{2}$ reaction. Activation energy based on $\mathrm{CHOCHO} / \mathrm{O}_{2} / \mathrm{N}_{2}$ study of Ref. [112].

(k) Fitted expression based on Ref. [113 - 119].

(l) This Study [23].

(m) Fitted expression based on Ref. [120 - 122]

(n) Fitted expression based on Ref. [99, 123 - 125].

(o) Used Troe relation [126], $\beta_{c} /\left(1-\beta_{c} 0.5\right)=\langle\Delta E\rangle_{a}$ all $/ F E k_{B} T$, to obtain $\beta_{c}$ from $\langle\Delta E\rangle_{\text {all }}$. Transition state frequencies obtained from [56]. Fitted expressions at one atmosphere are $k_{35}=10^{51.319} \mathrm{~T}^{-10.60} \mathrm{Exp}(-115.575 \mathrm{kcal} / \mathrm{mol} / \mathrm{RT}) \mathrm{sec}^{-1}$ and $\mathrm{k}_{166}=10^{14.919} \mathrm{~T}^{-0.50} \operatorname{Exp}(-13.045 \mathrm{kcal} / \mathrm{mol} / \mathrm{RT}) \mathrm{cm}^{3} / \mathrm{mol}-\mathrm{sec}$ with $\mathrm{M}=\mathrm{N}_{2}$. 
Table 4

Thermodynamic Properties

at 1 Atmosphere Standard State

\begin{tabular}{|c|c|c|c|}
\hline Species & $\begin{array}{l}\Delta \mathrm{H}_{\mathrm{f}}(298 \mathrm{~K}) \\
(\mathrm{kcal} / \mathrm{mol})\end{array}$ & $\begin{array}{l}S^{\circ}(298 \mathrm{~K}) \\
(\mathrm{cal} / \mathrm{mol})\end{array}$ & $\mathrm{C}_{\mathrm{p}}(\mathrm{T})$ Calculation \\
\hline $\mathrm{HO}_{2}$ & $3.8[127]$ & $54.7[21]$ & Kee et al. [21] \\
\hline $\mathrm{C}_{2} \mathrm{H}_{4} \mathrm{O}_{2} \mathrm{H}$ & $7.3[58]$ & $77.5[58]$ & Bozzelli/Dean [58] \\
\hline $\mathrm{C}_{2} \mathrm{H}_{4} \mathrm{O}$ & $-12.6[22]$ & $58.0[22]$ & Burcat [22] \\
\hline $\begin{array}{l}\mathrm{C}_{2} \mathrm{H}_{3} \mathrm{O} \\
{[128]^{\mathrm{b}}}\end{array}$ & 36.0 & 59.8 & $\begin{array}{c}\text { THERM: Primary } \mathrm{CH} \\
\text { bond option applied to } \\
\mathrm{C}_{2} \mathrm{H}_{4} \mathrm{O} \text { (Ethylene oxide) } \\
\text { parent: } \\
\mathrm{BDE}=100.6 \mathrm{kcal} / \mathrm{mol}\end{array}$ \\
\hline $\mathrm{C}_{2} \mathrm{H}_{3}$ & $70.4[32]$ & $55.5[21]$ & Kee et al. [21] \\
\hline СHOCHO & $-50.7[129]$ & $66.5[29]$ & $\begin{array}{l}\text { 2- } \mathrm{CO}(\mathrm{H})(\mathrm{C})^{\mathrm{a}}, 1-\mathrm{OI} \\
\text { Int. Rot. , }[130,131]\end{array}$ \\
\hline $\mathrm{CHOCO}$ & -16.8 & 68.9 & $\begin{array}{c}\text { Parent: C H O C H O } \\
\text { BD group CCJ }{ }^{*} \text { O }[128]^{b}\end{array}$ \\
\hline $\mathrm{CH}_{2}(\mathrm{~S})$ & $103.9[88]$ & $45.08[21]$ & Kee et al. [21] \\
\hline All other & & in Therm & mic Database [21] \\
\hline
\end{tabular}

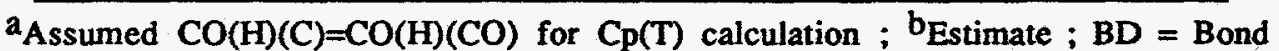
Dissociation ; $\mathrm{OI}=$ Optical Isomer, Int. Rot. = Internal Rotation, $\mathrm{rd}=$ radical

The $\mathrm{C}_{2} \mathrm{H}_{4}+\mathrm{H}=\mathrm{C}_{2} \mathrm{H}_{3}+\mathrm{H}_{2}$ reaction consumes only a small fraction $(\sim 8 \%)$ of the ethylene, though it is one of the primary hydrocarbon reactions for the formation of $\mathrm{H}_{2}$. The rate expression used is based on the fitted expression of Westbrook et al. [9].

\section{Vinyl Radical Kinetics:}

The kinetics of the $\mathrm{C}_{2} \mathrm{H}_{3}+\mathrm{O}_{2}$ reactions were initially taken from the theoretical analysis of Westmoreland [40]. We have also considered the $\mathrm{C}_{2} \mathrm{H}_{3}+\mathrm{O}_{2}=\mathrm{CH}_{2} \mathrm{CHO}+\mathrm{O}$-atom reaction as suggested by Bozzelli/Dean [41] The vinyl radical oxidation reactions examined in this study are: 


$$
\begin{aligned}
& \mathrm{C}_{2} \mathrm{H}_{3}+\mathrm{O}_{2}=\mathrm{CH}_{2} \mathrm{O}+\mathrm{HCO} \\
& \mathrm{C}_{2} \mathrm{H}_{3}+\mathrm{O}_{2}=\mathrm{CH}_{2} \mathrm{CHO}+\mathrm{O} \\
& \mathrm{C}_{2} \mathrm{H}_{3}+\mathrm{O}_{2}=\mathrm{CHOCHO}+\mathrm{H} \\
& \mathrm{C}_{2} \mathrm{H}_{3}+\mathrm{O}_{2}=\mathrm{C}_{2} \mathrm{H}_{2}+\mathrm{HO}_{2}
\end{aligned}
$$

The rate expressions for these reaction channels are dependent on a vinyl radical heat of formation value of $70.4 \mathrm{kcal} / \mathrm{mol}$. The $\mathrm{C}_{2} \mathrm{H}_{3}+\mathrm{O}_{2}$ product sets, rate expressions and the $\mathrm{C}_{2} \mathrm{H}_{3}$ heat of formation value as determined by the Bimolecular-QRRK studies [40, 41] are examined in this study.

Further discussion of the modeling results pertaining to the $\mathrm{C}_{2} \mathrm{H}_{3}+$ $\mathrm{O}_{2}$ kinetics is discussed in the Chemical Kinetic Model Validation and Analysis section of this study.

The Rao and Skinner rate expression [28] for $\mathrm{C}_{2} \mathrm{H}_{3}(+\mathrm{M})=\mathrm{C}_{2} \mathrm{H}_{2}+\mathrm{H}$ $(+M)$ was pressure corrected using the high pressure rate expression for the reverse reaction by Organ (as cited by Mackie [135]) and the thermodynamic equilibrium rate based on the $70.4 \mathrm{kcal} / \mathrm{mol}$ vinyl radical heat of formation value. Pressure correction was performed by using the Lindemann-Hinshelwood method.

Remaining Reaction Intermediates Kinetics:

Acetylene primarily reacts with $\mathrm{O}$-atom to form $\mathrm{CH}_{2}+\mathrm{CO}$, reaction (106), and $\mathrm{HCCO}+\mathrm{H}$ reaction (107). The product channels, rate expressions and branching ratio of $\mathrm{K}_{106} / \mathrm{K}_{107}=0.7$ involving the $\mathrm{C}_{2} \mathrm{H}_{2}$ $+O$ reaction were taken from Michael and Wagner [73]. The product channels and rate expressions for $\mathrm{C}_{2} \mathrm{H}_{2}+\mathrm{OH} \rightarrow$ Products, i.e. reactions (108), (109), (110) and (111), were taken from Miller and Melius [74].

Formaldehyde is primarily produced from $\mathrm{CH}_{2} \mathrm{OH}+\mathrm{O}_{2}=\mathrm{CH}_{2} \mathrm{O}+\mathrm{HO}_{2}$. $\mathrm{C}_{2} \mathrm{H}_{3}+\mathrm{O}_{2}=\mathrm{CH}_{2} \mathrm{O}+\mathrm{HCO}$ and $\mathrm{CH}_{3} \mathrm{O}(+\mathrm{M})=\mathrm{CH}_{2} \mathrm{O}+\mathrm{H}(+\mathrm{M})$ reactions and 
principally consumed by $\mathrm{OH}$ to make HCO. The Tsang and Hampson [4] rate expression was used for $\mathrm{CH}_{2} \mathrm{O}+\mathrm{OH}=\mathrm{HCO}+\mathrm{H}_{2} \mathrm{O}$.

Formyl radicals are quickly oxidized or decomposed to produce carbon monoxide. Formyl radical decomposition kinetics was taken from Timonen et al. [83] and formyl radical oxidation by $\mathrm{O}_{2}$ was determined by a compiled fit.

The primary route to methyl radical formation is from ethylene oxidation by $\mathrm{O}$-atom. The methyl radical produced is the precursor species to methane, methanol, and ethane formation as observed by Thornton. The reactions leading to methane, methanol and ethane formation are:

$$
\begin{aligned}
& \mathrm{CH}_{3}+\mathrm{HO}_{2}=\mathrm{CH}_{4}+\mathrm{O}_{2} \\
& \mathrm{CH}_{3}+\mathrm{H}(+\mathrm{M})=\mathrm{CH}_{4}(+\mathrm{M}) \\
& \mathrm{CH}_{3}+\mathrm{C}_{2} \mathrm{H}_{4}=\mathrm{CH}_{4}+\mathrm{C}_{2} \mathrm{H}_{3} \\
& \mathrm{CH}_{3}+\mathrm{OH}(+\mathrm{M})=\mathrm{CH}_{3} \mathrm{OH}(+\mathrm{M}) \\
& \mathrm{CH}_{3}+\mathrm{CH}_{3}(+\mathrm{M})=\mathrm{C}_{2} \mathrm{H}_{6}(+\mathrm{M})
\end{aligned}
$$

Carbon monoxide is primarily formed from the destruction reactions involving the formyl radical. Carbon monoxide is then principally converted to carbon dioxide by $\mathrm{CO}+\mathrm{OH} \rightarrow \mathrm{CO}_{2}+\mathrm{H}$ where the rate of Warnatz [5] was used. Carbon dioxide is primarily formed from carbon monoxide oxidization with minor production contribution from $\mathrm{CH}_{2}+\mathrm{O}_{2}$ $\rightarrow \mathrm{CO}_{2}+\mathrm{H}_{2}$ and $\mathrm{HCCO}+\mathrm{O}_{2} \rightarrow \mathrm{CO}_{2}+\mathrm{CO}+\mathrm{H}$.

\section{CHEMICAL KINETIC MODEL ANALYSIS AND VALIDATION}

Modeling efforts with the Westmoreland $\mathrm{C}_{2} \mathrm{H}_{3}+\mathrm{O}_{2}$ products and rate expressions proved to be unsuccessful in modeling the Thomton data set. Although the $\mathrm{CH}_{2} \mathrm{O}$ and $\mathrm{H}_{2}$ profiles were well predicted in comparison to the Thornton data set, the ethylene consumption and $\mathrm{CH}_{4}$, $\mathrm{CH}_{3} \mathrm{OH}, \mathrm{C}_{2} \mathrm{H}_{6}, \mathrm{CO}$ and $\mathrm{CO}_{2}$ profiles were underpredicted. Also, the 
acetylene profile showed a five fold overprediction for all temperatures. The acetylene profile was very sensitive to the $\mathrm{C}_{2} \mathrm{H}_{3}+\mathrm{O}_{2}=\mathrm{C}_{2} \mathrm{H}_{2}+\mathrm{HO}_{2}$ reaction relative to the other competing $\mathrm{C}_{2} \mathrm{H}_{3}+\mathrm{O}_{2}$ reaction channels while insensitive to the $\mathrm{C}_{2} \mathrm{H}_{3}(+\mathrm{M})=\mathrm{C}_{2} \mathrm{H}_{2}+\mathrm{H}(+\mathrm{M})$ reaction. A factor of four reduction to the Westmoreland rate expression for the $\mathrm{C}_{2} \mathrm{H}_{3}+\mathrm{O}_{2}=$ $\mathrm{C}_{2} \mathrm{H}_{2}+\mathrm{HO}_{2}$ product channel was tried while keeping all other reactions fixed. This improved the acetylene predictions to within a factor of two while the overall loss of ethylene remained largely unaffected. Since the vinyl radical is prinicipally consumed by $\mathrm{O}_{2}$, this result indicates that the $\mathrm{C}_{2} \mathrm{H}_{3}+\mathrm{O}_{2}=\mathrm{C}_{2} \mathrm{H}_{2}+\mathrm{HO}_{2}$ reaction is a minor vinyl consumption route relative to the $\mathrm{C}_{2} \mathrm{H}_{3}+\mathrm{O}_{2}=\mathrm{CH}_{2} \mathrm{O}+\mathrm{HCO}$ reaction. The $\mathrm{C}_{2} \mathrm{H}_{3}+\mathrm{O}_{2}=$ $\mathrm{C}_{2} \mathrm{H}_{2}+\mathrm{HO}_{2}$ reaction is only important for attaining an accurate acetylene prediction by the present study.

Chemical kinetic rate adjustment was then applied to the $\mathrm{C}_{2} \mathrm{H}_{3}(+\mathrm{M})=$ $\mathrm{C}_{2} \mathrm{H}_{2}+\mathrm{H}(+\mathrm{M})$ reaction. The vinyl decomposition reaction rate adjustment to the levels prescribed in the WP and DCB reaction sets were required to allow good agreement with the Thornton data set for all measured species except for acetylene at temperatures less than $1180 \mathrm{~K}$. No agreement could be achieved for temperatures in excess of $1180 \mathrm{~K}$. Furthermore, simultaneous modeling of the Dagaut et al. lean methane and ethane data sets showed reasonable agreement with the measured profiles for the parent hydrocarbon, the intermediates (i.e. C2H6, C2H4, $\mathrm{C} 2 \mathrm{H} 2, \mathrm{CH} 4$ and $\mathrm{CO}$ ) and by-product $\mathrm{CO} 2$ formed. Computer modeling studies determined that altering the vinyl decomposition or oxidation kinetic rates does not have a significant impact on the methane and ethane oxidation kinetics.

If a high vinyl decomposition chemical kinetic rate, on the order of the DCB prescribed rate, is considered acceptable, then a reevaluation of the vinyl decomposition process is in order. The high production rate of acetylene resulting from the fast vinyl decomposition pathway would indicate that the acetylene measurements of Thomton are in error. The alternative consideration of implementing the revised $\mathrm{KWKW}$ vinyl decomposition rate expression lowers the acetylene and $\mathrm{H}$-atom 
production rate. The vinyl radical then becomes exclusively consumed by $\mathrm{O}_{2}$, and the production loss of $\mathrm{H}$-atom (from $\mathrm{C}_{2} \mathrm{H}_{3} \rightarrow \mathrm{C}_{2} \mathrm{H}_{2}+\mathrm{H}$ ) compromises any modeling agreement with the Thornton data set.

Thus, modeling indicates that the Bozzelli and Dean suggested vinyl oxidation sequence of $\mathrm{O}_{2}$ addition to the vinyl followed by an $\mathrm{O}$-atom splitting off

$$
\mathrm{C}_{2} \mathrm{H}_{3}+\mathrm{O}_{2} \leftrightarrow \mathrm{C}_{2} \mathrm{H}_{3} \mathrm{OO} \leftrightarrow \mathrm{CH}_{2} \mathrm{CHO}+\mathrm{O}
$$

or simply,

$$
\mathrm{C}_{2} \mathrm{H}_{3}+\mathrm{O}_{2} \leftrightarrow . \mathrm{CH}_{2} \mathrm{CHO}\left(\mathrm{C}_{2} \mathrm{H}_{3} \mathrm{O} \cdot\right)+\mathrm{O}
$$

is likely to occur. Their analysis of the $\mathrm{C}_{2} \mathrm{H}_{3}+\mathrm{O}_{2}$ reaction favors the vinoxy (i.e. the carbon centered radical $\mathrm{CH}_{2} \mathrm{CHO}$ or. $\mathrm{CH}_{2} \mathrm{CHO}$ ) and $\mathrm{O}$-atom product channel over the $\mathrm{CH}_{2} \mathrm{O}+\mathrm{HCO}$ product channel for temperatures greater than $900 \mathrm{~K}$. This study initially used the Bimolecular-QRRK predicted $\mathrm{C}_{2} \mathrm{H}_{3}+\mathrm{O}_{2}=\mathrm{CH}_{2} \mathrm{CHO}+\mathrm{O}$ rate expression of 1.191E14 $\mathrm{T}-0.611$ $\exp (-2646 / \mathrm{T}) \quad \mathrm{cm}^{3} / \mathrm{mol}-\mathrm{sec}[70]$ based on the arguments presented by Bozzelli/Dean for the viability of this reaction. This rate was subsequently adjusted upward to $7.0 \mathrm{E} 14 \mathrm{~T}^{-0.611} \exp (-2646 / \mathrm{T}) \mathrm{cm}^{3} / \mathrm{mol}$ sec for complete agreement with the Thornton measured profiles. This rate expression differs by more than two orders of magnitude higher than the Westmoreland prediction [40] and lies a factor of three lower than the Bozzelli and Dean prediction [41] at the conditions of this study.

Modeling efforts readily support the $\mathrm{C}_{2} \mathrm{H}_{3}+\mathrm{O}_{2}$ channel leading to $\mathrm{CH}_{2} \mathrm{CHO}+\mathrm{O}$-atom as an extremely important reaction in the ethylene oxidation process. This result indicates that the Bozzelli/Dean intrepretation of the $\mathrm{C}_{2} \mathrm{H}_{3}+\mathrm{O}_{2}=\mathrm{CH}_{2} \mathrm{CHO}+\mathrm{O}$ reaction proceeding through a looser transition state than perceived by Westmoreland is correct as determined by this study. The $\mathrm{C}_{2} \mathrm{H}_{3}+\mathrm{O}_{2}=\mathrm{CH}_{2} \mathrm{CHO}+\mathrm{O}$-atom reaction followed by $\mathrm{CH}_{2} \mathrm{CHO}+\mathrm{M}=\mathrm{CH}_{2} \mathrm{CO}+\mathrm{H}+\mathrm{M}$ is a very potent chain branching process. The additional $\mathrm{O}$-atom source other than from $\mathrm{H}+\mathrm{O}_{2}$ $=\mathrm{OH}+\mathrm{O}$ allows for rapid ethylene oxidation by $\mathrm{O}$-atom. The reactive $\mathrm{H}$ atom produced from the vinoxy decomposition and from the $\mathrm{C}_{2} \mathrm{H}_{4}+\mathrm{O}$ atom reactions (i.e. reactions (51) and (52)) can further the oxidation of 
the ethylene. The subsequent $\mathrm{C}_{2} \mathrm{H}_{4}+\mathrm{O}$-atom reactions have the ability to produce methyl radical which eventually forms methane, methanol, and ethane. Figures 4 and 5 illustrate the agreement between the modelled and experimental measurements for the loss of ethylene and the reaction intermediates' formed due to the inclusion of $\mathrm{C}_{2} \mathrm{H}_{3}+\mathrm{O}_{2}=$ $\mathrm{CH}_{2} \mathrm{CHO}+\mathrm{O}$.

Modeling analysis is indeterminate toward obtaining the proper individual kinetic rates for the various $\mathrm{C}_{2} \mathrm{H}_{3}+\mathrm{O}_{2}$ product pathways since the vinyl radical is consumed principally by $\mathrm{O}_{2}$. However, sensitivity to the modeled predictions is strongly exhibited by the branching ratios selected. If the $\mathrm{C}_{2} \mathrm{H}_{3}+\mathrm{O}_{2}=\mathrm{CH}_{2} \mathrm{O}+\mathrm{HCO}$ reaction exhibits fall-off at high temperatures similar to the predicted kinetics

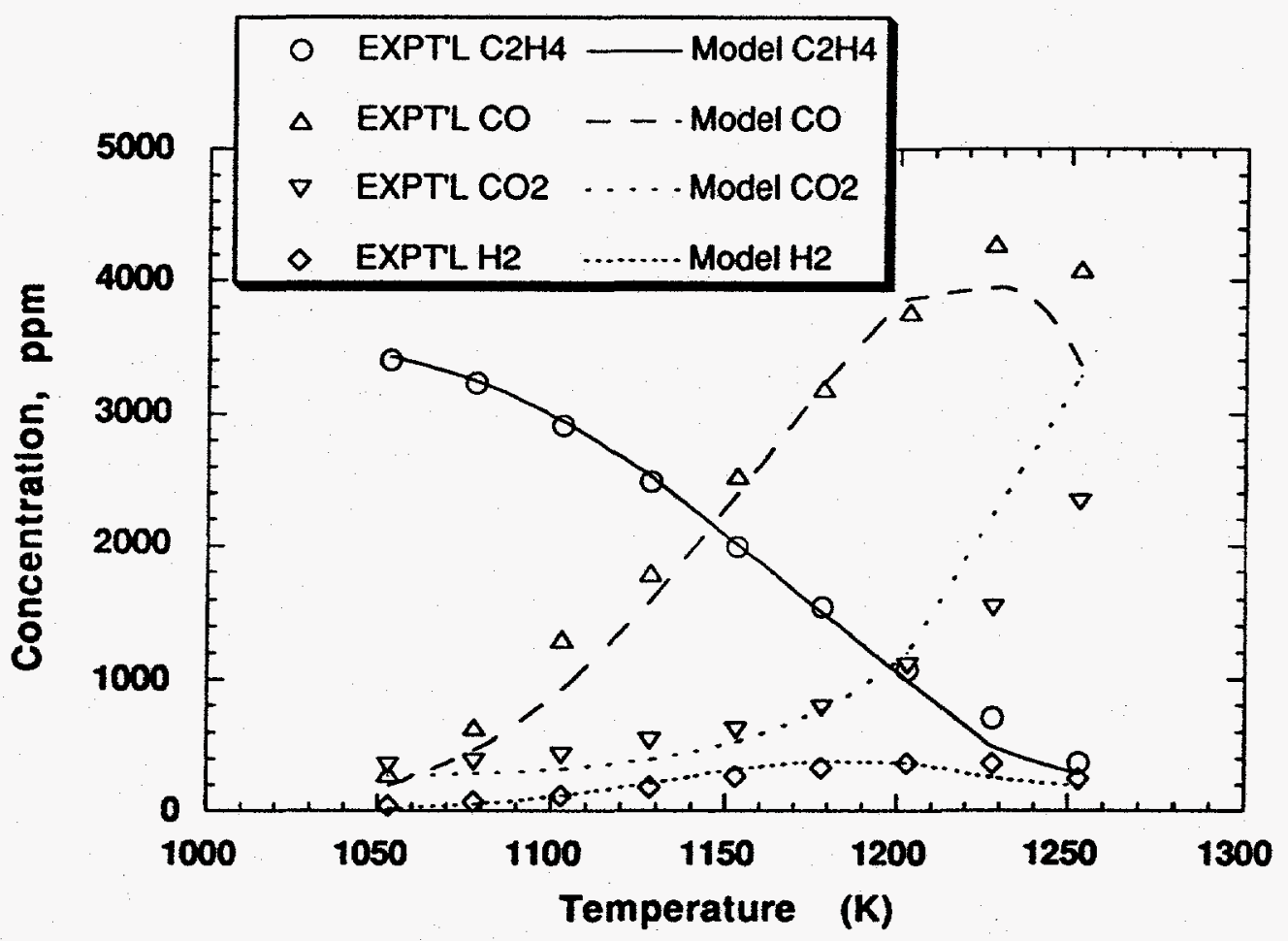

Figure 4: Comparison of predicted and experimental data of $\mathrm{C}_{2} \mathrm{H}_{4}, \mathrm{CO}, \mathrm{CO}_{2}$ and $\mathrm{H}_{2}:$ experimental (open symbols) from Thornton [1]; predicted curves from the compiled ethylene oxidation model listed in Table 3. 


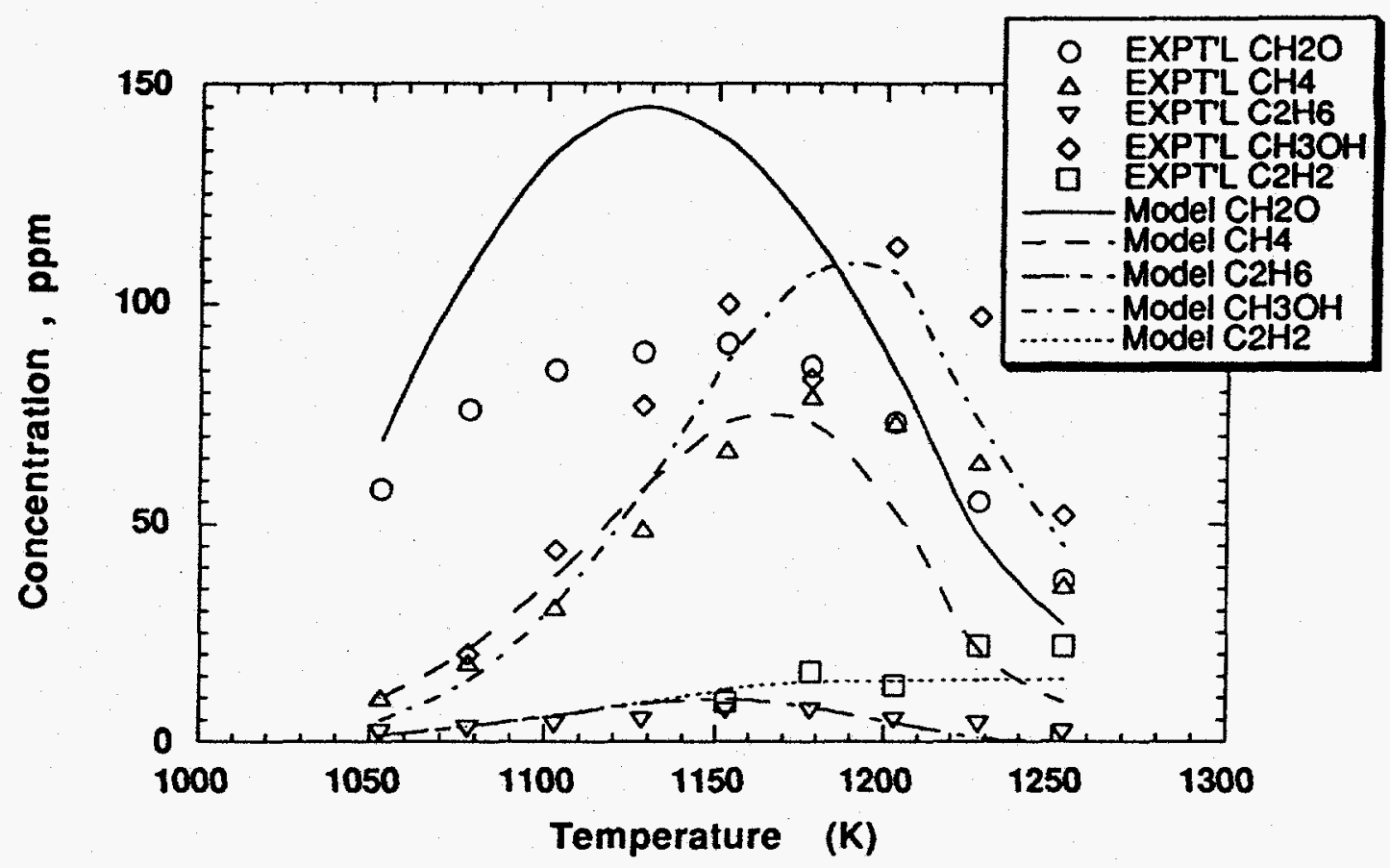

Figure 5: Comparison of predicted and experimental data of $\mathrm{CH}_{2} \mathrm{O}, \mathrm{CH}_{4}$, $\mathrm{CH}_{3} \mathrm{OH}, \mathrm{C}_{2} \mathrm{H}_{6}$ and $\mathrm{C}_{2} \mathrm{H}_{2}$ : experimental (open symbols) from Thornton [1]; predicted curves from the compiled ethylene oxidation model listed in Table 3.

of Westmoreland, then the branching ratios for the product sets, $\mathrm{CH}_{2} \mathrm{O}+\mathrm{HCO}: \mathrm{CH}_{2} \mathrm{CHO}+\mathrm{O}: \mathrm{C}_{2} \mathrm{H}_{2}+\mathrm{HO}_{2}$, are $1.0: 1.21: 0.052$ at $1053 \mathrm{~K}$ and 1.0 : $2.47: 0.080$ at $1253 \mathrm{~K}$ [Table 3 kinetics]. If the Gutman et al. [39] measured kinetic rate is used for the $\mathrm{C}_{2} \mathrm{H}_{3}+\mathrm{O}_{2}=\mathrm{CH}_{2} \mathrm{O}+\mathrm{HCO}$ reaction, no fall-off is exhibited for this reaction. Hence, the branching ratios for the aforementioned product sets would be 1.0: 1.19: 0.067 at $1053 \mathrm{~K}$ and 1.0 : $1.63: 0.068$ at $1253 \mathrm{~K}$ (where the kinetic rate of $\mathrm{C}_{2} \mathrm{H}_{3}+\mathrm{O}_{2}=\mathrm{CH}_{2} \mathrm{CHO}+\mathrm{O}$ would be $4.62 \mathrm{E} 15 \mathrm{~T}^{-0.611} \exp (-2646 / \mathrm{T}) \mathrm{cm}^{3} / \mathrm{mol}-\mathrm{sec}$ and $\mathrm{C}_{2} \mathrm{H}_{3}+\mathrm{O}_{2}=\mathrm{C}_{2} \mathrm{H}_{2}$ $+\mathrm{HO}_{2}$ would be $\left.3.00 \mathrm{E} 11 \mathrm{~cm}^{3} / \mathrm{mol}-\mathrm{sec}\right)$. We have averaged these branching ratios and obtained $1.0: 1.20: 0.06$ at $1053 \mathrm{~K}$ and $1.0: 2.05: 0.074$ at $1253 \mathrm{~K}$ for the product channels $\mathrm{CH}_{2} \mathrm{O}+\mathrm{HCO}: \mathrm{CH}_{2} \mathrm{CHO}+\mathrm{O}: \mathrm{C}_{2} \mathrm{H}_{2}+\mathrm{HO}_{2}$. The domination of the $\mathrm{C}_{2} \mathrm{H}_{3}+\mathrm{O}_{2}=\mathrm{CH}_{2} \mathrm{CHO}+\mathrm{O}$ pathway is expected to occur around $1000 \mathrm{~K}$ to $1100 \mathrm{~K}$ for one atmosphere pressure. 
Mechanism Analysis: The 1050K - 1180K Temperature Range

Reaction pathway analysis is performed at $1153 \mathrm{~K}$ using the presently compiled model. The analysis is conducted in order to identify the important ethylene oxidation pathways leading to by-product $\mathrm{CO}_{2}$.

The primary ethylene oxidation pathway is determined to be the following:

(1) $\mathrm{C}_{2} \mathrm{H}_{4}+\mathrm{O}=\mathrm{CH}_{3}+\mathrm{HCO}$

(2) $\mathrm{C}_{2} \mathrm{H}_{4}+\mathrm{O}=\mathrm{CH}_{2}+\mathrm{HCO}+\mathrm{H}$

(1) $\mathrm{CH}_{3}+\mathrm{OH}(+\mathrm{M})=\mathrm{CH}_{3} \mathrm{OH}(+\mathrm{M})$

$\mathrm{CH}_{3}+\mathrm{HO}_{2}=\mathrm{CH}_{3} \mathrm{O}+\mathrm{OH}$

$\mathrm{CH}_{3}+\mathrm{HO}_{2}=\mathrm{CH}_{4}+\mathrm{O}_{2}$

$\mathrm{CH}_{3}+\mathrm{CH}_{3}(+\mathrm{M})=\mathrm{C}_{2} \mathrm{H}_{6}(+\mathrm{M})$

$\mathrm{CH}_{3} \mathrm{OH}+\mathrm{OH}=\left(\mathrm{CH}_{3} \mathrm{O}\right.$ or $\left.\mathrm{CH}_{2} \mathrm{OH}\right)+\mathrm{H}_{2} \mathrm{O}$

$\mathrm{CH}_{3} \mathrm{O}(+\mathrm{M})=\mathrm{CH}_{2} \mathrm{O}+\mathrm{H}(+\mathrm{M})$

$\mathrm{CH}_{2} \mathrm{OH}+\mathrm{O}_{2}=\mathrm{CH}_{2} \mathrm{O}+\mathrm{HO}_{2}$

$\mathrm{CH}_{2} \mathrm{O}+\mathrm{OH}=\mathrm{HCO}+\mathrm{H}_{2} \mathrm{O}$

$\mathrm{HCO}+\mathrm{M}=\mathrm{H}+\mathrm{CO}+\mathrm{M}$

$\mathrm{HCO}+\mathrm{O}_{2}=\mathrm{CO}+\mathrm{HO}_{2}$

$\mathrm{CO}+\mathrm{OH}=\mathrm{CO}_{2}+\mathrm{H}$

(2) $\mathrm{CH}_{2}+\mathrm{O}_{2} \rightarrow \mathrm{CO}, \mathrm{H}_{2} \mathrm{O}, \mathrm{CO}_{2}, \mathrm{H}_{2}$ Products

$$
\mathrm{CO}+\mathrm{OH}=\mathrm{CO}_{2}+\mathrm{H}
$$

The $\mathrm{O}$-atom is principally formed from two sources. The $\mathrm{H}$-atoms produced from the $\mathrm{HCO}, \mathrm{CH}_{2} \mathrm{CHO}$ and $\mathrm{CH}_{3} \mathrm{O}$ decomposition reactions will react with $\mathrm{O}_{2}$ to make $\mathrm{OH}$ and the $\mathrm{O}$-atom, and the $\mathrm{C}_{2} \mathrm{H}_{3}$ oxidation reaction by $\mathrm{O}_{2}$ makes $\mathrm{CH}_{2} \mathrm{CHO}$ and the $\mathrm{O}$-atom. These two sources of $\mathrm{O}$-atom production are essential for promoting the $\mathrm{O}$-atom attack on the ethylene in steps (1) and (2) and providing a source of additional free radicals for further ethylene consumption. The $\mathrm{O}$-atom will preferentially react with the ethylene to form methyl and formyl radicals or methylene, formyl radical and $\mathrm{H}$-atom. The methyl radical is principally consumed by reactions involving $\mathrm{HO}_{2}$ and 
$\mathrm{OH}$ radicals. These reactions are $\mathrm{CH}_{3}+\mathrm{HO}_{2}=\mathrm{CH}_{3} \mathrm{O}+\mathrm{OH}$ and $\mathrm{CH}_{3}+\mathrm{OH}(+\mathrm{M})=$ $\mathrm{CH}_{3} \mathrm{OH}+(+\mathrm{M})$. The minor methyl radical consumption reactions are $\mathrm{CH}_{3}+$ $\mathrm{HO}_{2}=\mathrm{CH}_{4}+\mathrm{H}_{2} \mathrm{O}$ and $\mathrm{CH}_{3}+\mathrm{CH}_{3}(+\mathrm{M})=\mathrm{C}_{2} \mathrm{H}_{6}(+\mathrm{M})$. The methylene primarily reacts with $\mathrm{O}_{2}$ to form $\mathrm{CO}_{2}, \mathrm{CO}, \mathrm{H}_{2} \mathrm{O}$, and $\mathrm{H}_{2}$ products. The oxidized ethylene contribution from steps ( 1 and 2 ) creates formyl radicals which either decompose to produce $\mathrm{H}$-atoms or oxidize to form $\mathrm{HO}_{2}$ radicals. The formed $\mathrm{H}$-atom will add to $\mathrm{O}_{2}$ to make $\mathrm{HO}_{2}$ radical, but for the experimental conditions of the present study, the important $\mathrm{HO}_{2}$ producing pathway is $\mathrm{HCO}+\mathrm{O}_{2}=\mathrm{CO}+\mathrm{HO}_{2}$. The $\mathrm{HO}_{2}$ radical is primarily removed by $\mathrm{HO}_{2}+\mathrm{HO}_{2}=$ $\mathrm{H}_{2} \mathrm{O}_{2}+\mathrm{O}_{2}, \mathrm{HO}_{2}+\mathrm{OH}=\mathrm{H}_{2} \mathrm{O}+\mathrm{O}_{2}$, and $\mathrm{HO}_{2}+\mathrm{H}=\mathrm{OH}+\mathrm{OH}$.

The secondary, but extremely important, ethylene oxidation pathway is determined to be the following:

$$
\begin{aligned}
& \mathrm{C}_{2} \mathrm{H}_{4}+\mathrm{OH}=\mathrm{C}_{2} \mathrm{H}_{3}+\mathrm{H}_{2} \mathrm{O} \\
& \text { (1) } \mathrm{C}_{2} \mathrm{H}_{3}+\mathrm{O}_{2}=\mathrm{CH}_{2} \mathrm{CHO}+\mathrm{O} \\
& \text { (2) } \mathrm{C}_{2} \mathrm{H}_{3}+\mathrm{O}_{2}=\mathrm{CH}_{2} \mathrm{O}+\mathrm{HCO} \\
& \text { (1) } \mathrm{CH}_{2} \mathrm{CHO}+\mathrm{M}=\mathrm{CH}_{2} \mathrm{CO}+\mathrm{H}+\mathrm{M} \\
& \mathrm{CH}_{2} \mathrm{CO}+\mathrm{OH}=\mathrm{CH}_{2} \mathrm{OH}+\mathrm{CO} \\
& \mathrm{CH}_{2} \mathrm{CO}+\mathrm{OH}=\mathrm{HCCO}+\mathrm{H}_{2} \mathrm{O} \\
& \mathrm{CH}_{2} \mathrm{OH}+\mathrm{O}_{2}=\mathrm{CH}_{2} \mathrm{O}+\mathrm{HO}_{2} \\
& \mathrm{HCCO}+\mathrm{O}_{2}=\mathrm{CO} 2+\mathrm{CO}+\mathrm{OH} \\
& \mathrm{CH}_{2} \mathrm{O}+\mathrm{OH}=\mathrm{HCO}+\mathrm{H}_{2} \mathrm{O} \\
& \mathrm{HCO}+\mathrm{O}_{2}=\mathrm{CO}+\mathrm{HO}_{2} \\
& \mathrm{HCO}+\mathrm{M}=\mathrm{H}+\mathrm{CO}+\mathrm{M} \\
& \text { (2) } \mathrm{C}_{2} \mathrm{H}_{3}+\mathrm{O}_{2}=\mathrm{CH}_{2} \mathrm{O}+\mathrm{HCO} \\
& \mathrm{CH}_{2} \mathrm{O}+\mathrm{OH}=\mathrm{HCO}+\mathrm{H}_{2} \mathrm{O} \\
& \text { (1a) } \mathrm{HCO}+\mathrm{M}=\mathrm{H}+\mathrm{CO}+\mathrm{M} \\
& \text { (2a) } \mathrm{HCO}+\mathrm{O}_{2}=\mathrm{CO}+\mathrm{HO}_{2} \\
& \text { Net Overall Reaction: (1 a) } \mathrm{C}_{2} \mathrm{H}_{3}+\mathrm{OH}+\mathrm{O}_{2} \rightarrow 2 \mathrm{CO}+\mathrm{H}_{2} \mathrm{O}+2 \mathrm{H} \\
& \text { (2a) } \mathrm{C}_{2} \mathrm{H}_{3}+\mathrm{OH}+3 \mathrm{O}_{2} \rightarrow 2 \mathrm{CO}+\mathrm{H}_{2} \mathrm{O}+2 \mathrm{HO}_{2}
\end{aligned}
$$


Once the $\mathrm{OH}$ radical concentration is established within the stirred reactor, the $\mathrm{OH}$ radical consumes the $\mathrm{C}_{2} \mathrm{H}_{4}$ to produce $\mathrm{C}_{2} \mathrm{H}_{3}$ and $\mathrm{H}_{2} \mathrm{O}$. The $\mathrm{C}_{2} \mathrm{H}_{3}+\mathrm{O}_{2}=\mathrm{CH}_{2} \mathrm{CHO}+\mathrm{O}$ reaction followed by $\mathrm{CH}_{2} \mathrm{CHO}=\mathrm{CH}_{2} \mathrm{CO}+\mathrm{H}$ is a very potent chain branching process for ethylene oxidation. This pathway allows for the formation of $\mathrm{O}$-atom, $\mathrm{H}$-atom, and ketene species. Step (1) is an essential pathway required by the present model to accurately model the Thornton data set. The ketene species is primarily removed by $\mathrm{OH}$ addition to produce $\mathrm{CH}_{2} \mathrm{OH}$ and $\mathrm{CO}$. The $\mathrm{CH}_{2} \mathrm{CO}+\mathrm{OH}=\mathrm{HCCO}+\mathrm{H}_{2} \mathrm{O}$ reaction is a minor ketene consumption path. The $\mathrm{CH}_{2} \mathrm{OH}$ produced from the ketene is quickly oxidized by $\mathrm{O}_{2}$ to make $\mathrm{CH}_{2} \mathrm{O}$ and $\mathrm{HO}_{2}$. In step (2), the net overall reaction sequence indicates that the $\mathrm{C}_{2} \mathrm{H}_{3}+\mathrm{O}_{2}=\mathrm{CH}_{2} \mathrm{O}+$ HCO pathway eventually produces either reactive $\mathrm{H}$-atoms or unreactive $\mathrm{HO}_{2}$ radicals. The dominance of either the $\mathrm{H}$-atom or $\mathrm{HO}_{2}$ production pathway is strictly determined by the nature of the formyl radical destruction. For the lower temperatures of this study, formyl radical is primarily removed by step (2a). Temperatures in the $1200 \mathrm{~K}$ to $1253 \mathrm{~K}$ range, formyl radical is consumed equally by steps (1a) and (2a).

\section{Model Analysis: Temperatures Greater Than $1180 \mathrm{~K}$}

The good agreement represented by the ethylene oxidation model predictions against the Thomton measurements in the $1180 \mathrm{~K}-1250 \mathrm{~K}$ temperature range differs substantially from the WP and DCB reaction set predictions. The underlying difference in the numerical predictions is due to the kinetics and product pathways involving the vinyl radical and the fundamental role the reaction intermediates (such as $\mathrm{HO}_{2}, \mathrm{CH}_{2} \mathrm{O}, \mathrm{CH}_{2} \mathrm{CO}, \mathrm{CO}$ and $\mathrm{CH}_{3}$ ) play in moderating the dominant $\mathrm{OH}$ radical concentration within the stirred reactor.

Previously, Westbrook and Pitz [2] explained the observed disagreement between their computed results and the Thornton measurements in the 1180 - $1250 \mathrm{~K}$ temperature range as being caused by the prescence of turbulent species fluctuations within the reactor and ruled out the possibility that a mechanistic change could explain 
the Thornton measurements in this temperature regime. This explanation was later supported by the chemical kinetic computational investigation of Dagaut/Cathonnet/Boettner [16]. This has been previously shown in Figure 1.

The presently compiled ethylene oxidation model supports the theory that abundant formation of $\mathrm{HO}_{2}, \mathrm{CH}_{2} \mathrm{O}, \mathrm{CH}_{2} \mathrm{CO}, \mathrm{CO}$, and $\mathrm{CH}_{3}$ competes with $\mathrm{C}_{2} \mathrm{H}_{4}$ for $\mathrm{OH}$ at the highest temperatures of the data set. This results in the $\mathrm{C}_{2} \mathrm{H}_{4}+\mathrm{OH}=\mathrm{C}_{2} \mathrm{H}_{3}+\mathrm{H}_{2} \mathrm{O}$ reaction experiencing a reduced share of $\mathrm{OH}$ concentration needed for further ethylene consumption as exhibited in Table 5. The competition for $\mathrm{OH}$ at the higher temperatures would explain why significant amounts of ethylene remain within the stirred reactor. Furthermore, the abundance of the aforementioned reaction intermediates prevents the potent chain branching sequence $\left(\mathrm{C}_{2} \mathrm{H}_{4}+\mathrm{OH}=\mathrm{C}_{2} \mathrm{H}_{3}+\mathrm{H}_{2} \mathrm{O}, \mathrm{C}_{2} \mathrm{H}_{3}+\mathrm{O}_{2}=\right.$ $\mathrm{CH}_{2} \mathrm{CHO}+\mathrm{O}, \mathrm{CH}_{2} \mathrm{CHO}+\mathrm{M}=\mathrm{CH}_{2} \mathrm{CO}+\mathrm{H}+\mathrm{M}, \mathrm{H}+\mathrm{O}_{2}=\mathrm{OH}+\mathrm{O}$ ) from producing an over abundance of free radicals in this temperature range. In effect, the stirred reactor remains chemically controlled. Therefore, the present study concludes that reasonable spatial homogeneity was maintained within the reactor for as high as $1253 \mathrm{~K}$.

Table 5

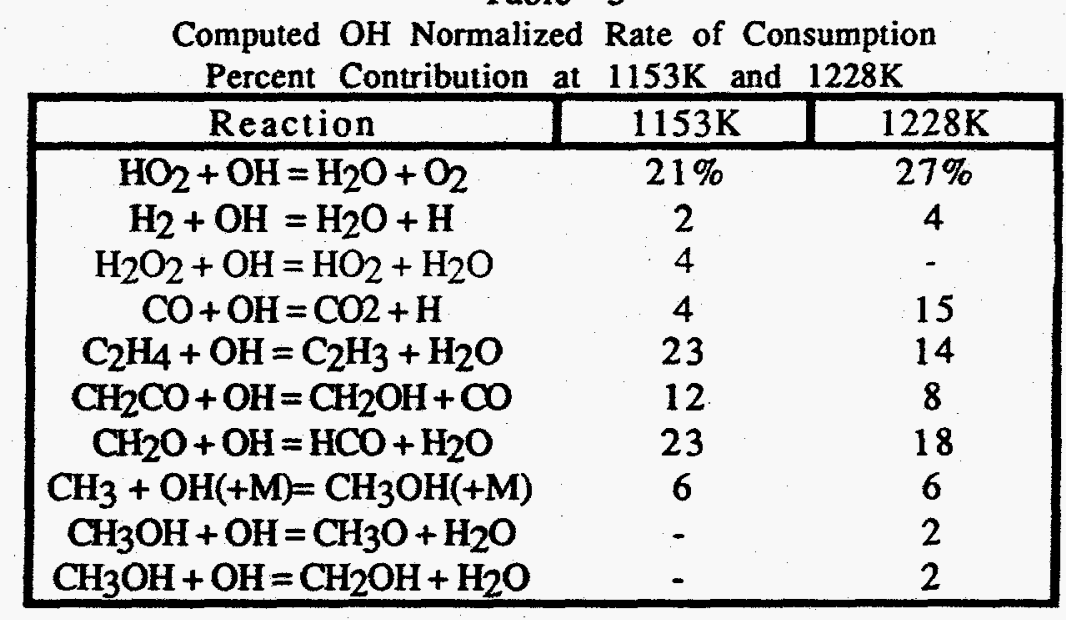

The fast rate of ethylene oxidiation obtained with the WP and DCB mechanisms is the result of fairly high rates of $\mathrm{C}_{2} \mathrm{H}_{3}(+\mathrm{M})=\mathrm{C}_{2} \mathrm{H}_{2}+\mathrm{H}(+\mathrm{M})$ 
which promotes excessive chain branching at the higher temperatures. In particular, the coupling of the acetylene production and the build-up of $\mathrm{O}$-atom to sufficient concentrations at the high temperature end of the data set unleashes a potent chain branching process. This is exemplified by the following reaction sequence,

$$
\begin{gathered}
\mathrm{C}_{2} \mathrm{H}_{4}+\mathrm{OH}=\mathrm{C}_{2} \mathrm{H}_{3}+\mathrm{H}_{2} \mathrm{O} \\
\mathrm{C}_{2} \mathrm{H}_{3}(+\mathrm{M})=\mathrm{C}_{2} \mathrm{H}_{2}+\mathrm{H}(+\mathrm{M}) \\
\mathrm{H}+\mathrm{O}_{2}=\mathrm{OH}+\mathrm{O} \\
\mathrm{C}_{2} \mathrm{H}_{4}+\mathrm{O}=\mathrm{CH}_{3} \mathrm{CO}+\mathrm{H} \text { (WP only) } \\
\mathrm{C}_{2} \mathrm{H}_{4}+\mathrm{O}=\mathrm{CH}_{3}+\mathrm{HCO} \text { (DCB only) } \\
\mathrm{C}_{2} \mathrm{H}_{4}+\mathrm{O} \rightarrow \mathrm{CH}_{2}+\mathrm{HCO}+\mathrm{H} \text { (DCB only) } \\
\mathrm{C}_{2} \mathrm{H}_{2}+\mathrm{O}=\mathrm{HCCO}+\mathrm{H} \\
\mathrm{C}_{2} \mathrm{H}_{2}+\mathrm{O}=\mathrm{CH}_{2}+\mathrm{CO} \\
\mathrm{HCCO}+\mathrm{O}_{2}=\mathrm{CO}+\mathrm{CO}+\mathrm{OH} \text { (DCB only) } \\
\mathrm{HCCO}+\mathrm{H}=\mathrm{CH}_{2}+\mathrm{CO} \\
\mathrm{HCCO}+\mathrm{O}=\mathrm{CO}_{\mathrm{HCO}}+\mathrm{H} \\
\mathrm{CH}_{2}+\mathrm{O}_{2}=\mathrm{CO}_{2}+\mathrm{H}+\mathrm{H} \\
\mathrm{CH}_{2}+\mathrm{O}_{2}=\mathrm{CO}_{2} \mathrm{OH}+\mathrm{H} \\
\mathrm{CO}+\mathrm{OH}=\mathrm{CO}+\mathrm{H} \\
\mathrm{HCO} \rightarrow \mathrm{H} \text { or } \mathrm{HO}_{2}
\end{gathered}
$$

which produces an over abundance of reactive free radicals that eventually consumes all of the ethylene at the higher temperatures of the data set.

The principal difference between this study's ethylene oxidation model and the WP and DCB mechanisms is the importance of vinyl oxidation kinetics, in particular, the $\mathrm{C}_{2} \mathrm{H}_{3}+\mathrm{O}_{2}=\mathrm{CH}_{2} \mathrm{CHO}+\mathrm{O}$ reaction. The reaction sequence for vinyl oxidation allows for rapid chain branching and favors the formation of stable products such as formaldehyde, methane and methanol. Acetylene kinetics does not play a significant role in the ethylene oxidation process as noted in the Thornton data set and supported by the presently compiled ethylene 
oxidation mechanism. This finding differs from the proposed ethylene oxidation mechanism of Westbrook/Pitz and Dagaut/Cathonnet/Boettner which favor considerable participation of acetylene kinetics in the ethylene oxidation process.

This study supports the viability of the $\mathrm{C}_{2} \mathrm{H}_{3}+\mathrm{O}_{2}=\mathrm{CH}_{2} \mathrm{CHO}+\mathrm{O}$ reaction. Implementation of this reaction must be considered for high temperature combustion chemistry modeling studies.

\section{SUMM AR Y}

The reported mechanisms of WP and DCB were used to understand the important features of the ethylene oxidation chemistry. The DCB mechanism showed agreement with the measured ethylene profile at the lower temperatures of the data set and for an extended temperature range compared to the WP mechanism. This was due to the heavy reliance on the $\mathrm{C}_{2} \mathrm{H}_{3}(+M)=\mathrm{C}_{2} \mathrm{H}_{2}+\mathrm{H}(+\mathrm{M})$ reaction by the $\mathrm{DCB}$ mechanism as the predominant vinyl consumption reaction. Both mechanisms showed a lack of agreement with the Thornton measurements, in particular, the acetylene profile was overpredicted by a factor of 20 to 30 . This suggested that the $\mathrm{C}_{2} \mathrm{H}_{3}(+\mathrm{M})=\mathrm{C}_{2} \mathrm{H}_{2}+\mathrm{H}(+\mathrm{M})$ reaction is not the prominent vinyl destruction process for the conditions examined.

An ethylene oxidation mechanism was developed to address the lack of agreement between the modeled concentrations based on the DCB and WP mechanisms and the Thomton data set, and the large rates of vinyl decomposition of the WP and DCB mechanisms relative to the results of the recent shock tube studies.

The model made use of the Westmoreland rate parameters for the important product sets involving the $\mathrm{C}_{2} \mathrm{H}_{3}+\mathrm{O}_{2}$ reaction. The modeling results involving the ethylene and the reaction intermediates proved unsuccessful with the Westmoreland $\mathrm{C}_{2} \mathrm{H}_{3}+\mathrm{O}_{2}$ predicted kinetics. 
The $\mathrm{C}_{2} \mathrm{H}_{3}+\mathrm{O}_{2}$ pathway to $\mathrm{CH}_{2} \mathrm{CHO}+\mathrm{O}$-atom proved to be a very important reaction in the ethylene oxidative pyrolysis. The very potent chain branching sequence of $\mathrm{C}_{2} \mathrm{H}_{3}+\mathrm{O}_{2} \rightarrow \mathrm{CH}_{2} \mathrm{CHO}+\mathrm{O}$-atom followed by $\mathrm{CH} 2 \mathrm{CHO}+\mathrm{M} \rightarrow \mathrm{CH} 2 \mathrm{CO}+\mathrm{H}+\mathrm{M}$ is needed to accurately model the Thomton ethylene data set.

Reaction pathway analysis was performed at $1153 \mathrm{~K}$ to determine the important ethylene oxidation oxidation pathways leading to by-product $\mathrm{CO}_{2}$.

The primary ethylene oxidation pathway was determined to be the $\mathrm{C} 2 \mathrm{H} 4$ $+\mathrm{O}$-atom pathway. This oxidation sequence is described as the following:

$$
\begin{aligned}
& \mathrm{C}_{2} \mathrm{H}_{4}+\mathrm{O}=\mathrm{CH}_{3}+\mathrm{HCO} \\
& \mathrm{CH}_{3}+\mathrm{OH}(+\mathrm{M})=\mathrm{CH}_{3} \mathrm{OH}(+\mathrm{M}) \\
& \mathrm{CH}_{3}+\mathrm{HO}_{2}=\mathrm{CH}_{3} \mathrm{O}+\mathrm{OH} \\
& \mathrm{CH}_{3}+\mathrm{HO}_{2}=\mathrm{CH}_{4}+\mathrm{O}_{2} \\
& \mathrm{CH}_{3}+\mathrm{CH}_{3}(+\mathrm{M})=\mathrm{C}_{2} \mathrm{H}_{6}(+\mathrm{M}) \\
& \mathrm{CH}_{3} \mathrm{OH}+\mathrm{OH}=\left(\mathrm{CH}_{3} \mathrm{O} \text { or } \mathrm{CH}_{2} \mathrm{OH}\right)+\mathrm{H}_{2} \mathrm{O} \\
& \left.\mathrm{CH}_{3} \mathrm{O}+\mathrm{M}\right)=\mathrm{CH}_{2} \mathrm{O}+\mathrm{H}(+\mathrm{M}) \\
& \mathrm{CH}_{2} \mathrm{OH}+\mathrm{O}_{2}=\mathrm{CH}_{2} \mathrm{O}+\mathrm{HO}_{2} \\
& \mathrm{CH}_{2} \mathrm{O}+\mathrm{OH}=\mathrm{HCO}+\mathrm{H}_{2} \mathrm{O} \\
& \mathrm{HCO}_{+} \mathrm{M}=\mathrm{H}+\mathrm{CO}_{+} \mathrm{M} \\
& \mathrm{HCO}+\mathrm{O}=\mathrm{CO}+\mathrm{HO}_{2} \\
& \mathrm{CO}+\mathrm{OH}=\mathrm{CO}_{2}+\mathrm{H}
\end{aligned}
$$

and,

$$
\begin{aligned}
& \mathrm{C}_{2} \mathrm{H}_{4}+\mathrm{O}=\mathrm{CH}_{2}+\mathrm{HCO}+\mathrm{H} \\
& \mathrm{CH}_{2}+\mathrm{O}_{2} \rightarrow \mathrm{CO}, \mathrm{H}_{2} \mathrm{O}, \mathrm{CO}_{2}, \mathrm{H}_{2} \text { Products } \\
& \mathrm{CO}+\mathrm{OH}=\mathrm{CO}+\mathrm{H}
\end{aligned}
$$

The secondary, but extremely important, ethylene oxidation pathway is the $\mathrm{C} 2 \mathrm{H} 4+\mathrm{OH}$ radical pathway. This oxidation sequence is described as the following: 


$$
\mathrm{C}_{2} \mathrm{H}_{4}+\mathrm{OH}=\mathrm{C}_{2} \mathrm{H}_{3}+\mathrm{H}_{2} \mathrm{O}
$$

followed by,

$$
\begin{aligned}
& \mathrm{C}_{2} \mathrm{H}_{3}+\mathrm{O}_{2}=\mathrm{CH}_{2} \mathrm{CHO}+\mathrm{O} \\
& \mathrm{CH}_{2} \mathrm{CHO}+\mathrm{M}=\mathrm{CH}_{2} \mathrm{CO}+\mathrm{H}+\mathrm{M} \\
& \mathrm{CH}_{2} \mathrm{CO}+\mathrm{OH}=\mathrm{CH}_{2} \mathrm{OH}+\mathrm{CO} \\
& \mathrm{CH}_{2} \mathrm{CO}+\mathrm{OH}=\mathrm{HCCO}+\mathrm{H}_{2} \mathrm{O} \\
& \mathrm{CH}_{2} \mathrm{OH}+\mathrm{O}_{2}=\mathrm{CH}_{2} \mathrm{O}+\mathrm{HO}_{2} \\
& \mathrm{HCCO}+\mathrm{O}_{2}=\mathrm{CO}+\mathrm{CO}+\mathrm{OH} \\
& \mathrm{CH}_{2} \mathrm{O}+\mathrm{OH}_{2}=\mathrm{HCO}+\mathrm{H}_{2} \mathrm{O} \\
& \mathrm{HCO}_{2} \mathrm{O}_{2}=\mathrm{CO}+\mathrm{HO}_{2} \\
& \mathrm{HCO}+\mathrm{M}=\mathrm{H}+\mathrm{CO}+\mathrm{M} \\
& \mathrm{CO}+\mathrm{OH}=\mathrm{CO}_{2}+\mathrm{H}
\end{aligned}
$$

and,

$$
\begin{aligned}
& \mathrm{C}_{2} \mathrm{H}_{3}+\mathrm{O}_{2}=\mathrm{CH}_{2} \mathrm{O}+\mathrm{HCO} \\
& \mathrm{CH}_{2} \mathrm{O}+\mathrm{OH}=\mathrm{HCO}+\mathrm{H}_{2} \mathrm{O} \\
& \mathrm{HCO}+\mathrm{M}=\mathrm{H}+\mathrm{CO}+\mathrm{M} \\
& \mathrm{HCO}+\mathrm{O}_{2}=\mathrm{CO}+\mathrm{HO}_{2} \\
& \mathrm{CO}+\mathrm{OH}=\mathrm{CO}_{2}+\mathrm{H}
\end{aligned}
$$

Good agreement between the compiled model's predictions and the experimental measurements were attained for the $1053 \mathrm{~K}$ to $1253 \mathrm{~K}$ temperature range.

The $\mathrm{C}_{2} \mathrm{H}_{3}+\mathrm{O}_{2}$ reaction to form $\mathrm{CH}_{2} \mathrm{CHO}+\mathrm{O}$ proved to play an integral part in the ethylene oxidation process and must be used in high temperature combustion chemistry modeling studies.

\section{Acknowledgement}

This work was carried out under the auspices of the U.S. Department of Energy by the Lawrence Livermore National Laboratory under contract No. W-7405-ENG-48. 


\section{Bibllography}

1. Thornton, M.M.: PhD Thesis, University of Washington, 1989.

2. Westbrook, C.K.; Thornton, M.M.; Pitz, W.J.; and Malte, P.C.:

Twenty-Second Symposium (International) on Combustion, 863 . The Combustion Institute, 1988.

3. Dagaut, P.; Cathonnet, M.; and Boettner, J.C.:

Int. J. Chem. Kinet., 23, 437 , (1991).

4. Tsang, W.; and Hampson, R.F.: J. Phys. Chem. Ref. Data, 15, 1095,(1986).

5. Warnatz, J.: In Combustion Chemistry; (Gardiner, W.C., Ed.); Chapter 5, Springer-Verlag , 1984.

6. Chakir, A.; Cathonnet, M.; Boettner, J.C.; and Gaillard, F.: Combust. Sci. and Tech., 65, 207, (1989).

7. Pitz,W.J.; Westbrook,C.K.; Proscia,W.M.; and Dryer, F.L.: Twentieth Symposium (International) on Combustion, 831. The Combustion Institute, 1985.

8. Brezinsky, K.: Prog. Energy Combust. Sci., 12, 1, (1986).

9. Westbrook, C.K.; Dryer, F.L.; and Schug, K.P.: Nineteenth Symposium (International) on Combustion, 153, The Combustion Institute, 1982.

10. Westbrook, C.K.: Combust. Flame, 46, 191, (1982).

11. Westbrook, C.K.; Dryer, F.L.; and Schug, K.P.: Combust. Flame, 52, 299, (1983).

12. Wilk,R.D.; Cernansky,N.P.; Westbrook,C.K.; and Pitz, W.J.: Twenty-Third Symposium (International) on Combustion, 203, The Combustion Institute, 1990.

13. Cathonnet, M.; Gaillard, F.; Boettner, J.C.; Cambray, P.; Karmed, D.; and Bellet, J.C.: Twentieth Symposium (International) on Combustion, 819, The Combustion Institute, 1984. 
14. Dagaut, P.; Cathonnet, M.; Gaillard, F.; Boettner, J.C.;

Rouan, J.P.; and James, H.: Prog. Astro. and Aeronaut., 105, 377, (1986).

15. Dagaut, P.; Cathonnet, M.; Boettner, J.C.; and Gaillard, F.:

Combustion and Flame, $71,295,(1988)$.

16. Dagaut, P.; Boettner, J.C.; and Cathonnet, M.:

Int. J. Chem. Kinet., 22, 641, (1990).

17. Tully, F.P.: Chem. Phys. Lett., 143, 510, (1988).

18. Thornton, M.M.; Malte, P.C.; and Crittenden, A.L.:

Twenty-First Symposium (International) on Combustion, 979, The Combustion Institute, 1986.

19. Thornton, M.M.; Malte, P.C.; and Crittenden, A.L.:

Combust. Sci. Tech., 54, 275, 1987.

20. Glarborg, P.; Kee, R.J.; Grcar, J.F.; and Miller, J.A.: Sandia National Laboratory, Albuquerque, N.M., SAND86-8209, 1986.

21. Kee, R.J.; Rupley, F.M.; and Miller, J.A.: Sandia National Laboratory, Albuquerque, N.M., SAND87-8215B, 1987.

22. Burcat, A.: In Combustion Chemistry; (Gardiner, W.C., Ed.); Chapter 8, Springer-Verlag , 1984.

23. Marinov, N.M.: PhD Thesis, University of Washington, 1993.

24. Garo, A.; Westmoreland, P.R.; Howard, J.R.; and Longwell, J.P.: Combustion and Flame, 72,271 , (1988) .

25. Baulch, D.L.; Cobos, C.J.; Cox, R.A.; Esser, C.; Frank, P.; Just, Th.; Kerr, J.A.; Pilling, M.J.; Troe, J.; Walker, R.W.; and Warnatz, J.: J. Phys. Chem. Ref. Data, 21, 411, (1992).

26. Miller, J.A., and Bowman, C.T.: Prog. Energy Combust. Sci., 15, 287, (1989).

27. Kiefer, J.H.; Wei, H.C.; Kern, R.D.; and Wu, C.H.:

Int. J. Chem. Kinet., 17, 225, (1985).

28. Rao, V.S. and Skinner, G.B.: J. Phys. Chem., 92, 6313, (1988). 
29. Ayranci, G. and Back, M.H.: Int. J. Chem. Kinet., 15, $83,(1983)$.

30. Losssing, F.P.: Can. J. Chem., 49, 357, (1971).

31. Shiromaru, H.; Achiba, Y.; Kimura, K.; and Lee, Y.T.:

J. Phys. Chem., 21, 17, (1987).

32. McMillian, D.F. and Golden, D.M.: Annu. Rev. Phys. Chem., 33. 493, (1982).

33. Devrees, D.J.; Mclver, Jr., R.T.; and Hehre, W.J.:

J. Am. Chem. Soc., 102, 3334, (1980).

34. Sharma, R.B.; Semo, N.M.; and Koski, W.S.:

Int'I J. Chem. Kinetics, 17, 831, (1985).

35. Ervin, K.M.; Gronert, S.; Barlow, S.E.; Gilles, M.K.; Harrison, A.G.; Bierbaum, V.M.; Depuy, C.H.,; Lineberger, W.C.; and Ellison, G.B: J. Am. Chem. Soc., 112, 5750, (1990).

36. Benson, S.W. and Haugen, G.R.: J. Phys. Chem., 71, 1735, (1967).

37. Payne, W.A. and Stief, L.J.: J. Chem. Phys., 64, 1150, (1976).

38. Sugarawa, K.; Okazaki, K.; and Sato, S.:

Bull. Chem. Soc. Jpn., 54, 2878, (1981).

39. Slagle, I.R.; Park, J-Y.; Heaven, M.C.; and Gutman, D.:

J. Amer. Chem. Soc., 106, 4356 , (1984).

40. Westmoreland, P.R.: Combust. Sci. Tech., 82, 15, (1992).

41. Bozzelli, J.W. and Dean, A.M.: J. Phys. Chem., 97. 4427, (1993).

42. Peck, R.E.; Glarborg, P.; and Johnsson, J.E.:

Combust. Sci. Tech., 76, 81, (1991).

43. Baldwin, R.R. , and Walker, R.W.: Eighteenth Symposium (International) on Combustion, 819. The Combustion Institute, 1981. 
44. Park, J-Y.; Heaven, M.C.; and Gutman, D.:

Chem. Phys. Letters, 104, 469, (1984).

45. Just, Th..: Twenty-Fifth Symposium (International)

on Combustion, to be published (1995).

46. Wagner, A.F.; Slagle, I.R.; Sarzynski, D.; and Gutman, D.:

J. Phys. Chem., 44, 1853, (1990).

47. Dagaut, P.; Boettner, J.C.; and Cathonnet, M.:

Combust. Sci. Tech., 77,127, (1991).

48. Cherian,M.A., Rhodes,P., Simpson,R.J. and Dixon-Lewis, G.:

Phil. Trans. Roy. Soc. London, A303, 181, (1981).

49. Brouwer, L.; Cobos, C.J.; Troe, J.; Dubai, H.R.; and Crim, F.F.:

J. Chem. Phys., 86, 6171, (1987).

50. Harding, L.B. and Wagner, A.F.: Twenty-Second Symposium (International) on Combustion, 983, The Combustion Institute, 1988.

51. Masten, D.A.; Hanson, R.K.; and Bowman, C.T.:

J. Phys. Chem., 94, 7119, (1990).

52. Hippler, H.; Troe, J.; and Willner, J.: J. Chem. Phys., 93, 1755, (1990).

53. Sutherland,J.W.; Michael,J.V.; Pirraglia,A.N.; Nesbitt,F.L.; and Klemm, R.B.: Twenty-First Symposium (International) on Combustion, 929, The Combustion Institute, 1986.

54. Walter, D.; Grotheer, H.H.; Davies, J.W.; Pilling, M.J.; and Wagner, A.F.: Twenty-Third Symposium (International) on Combustion, 107. The Combustion Institute, 1990.

55. Klemm,R.B.; Sutherland,J.W.; Patterson,P.M.; and Tanzana,T.:

Twenty-Fourth Symposium (International) on

Combustion, Poster 53, The Combustion Institute.

56. Stewart, P.H.; Larson, C.W.; and Golden, D.M.:

Combustion and Flame, 75, 25, (1989). 
57. Slagle I.R.; Sarzynski, D.; Gutman, D.; Miller, J.A.; and Melius, C.F.: J. Chem. Soc., Faraday Trans. 2, 84, 491 , (1988).

58. Bozzelli, J.W. and Dean, A.M.: J. Phys. Chem., 94. 3313, (1990).

59. Atkinson, R.: J. Phys. Chem. Ref. Data, Monograph No. 1, (1989).

60. Klemm, R.B.; Sutherland, J.W.; Wickramaaratchi, M.A.; and Yarwood, G.: J. Phys. Chem., 94, 3354, (1990).

61. Lightfoot, P.D. and Pilling, M.J.: J. Phys. Chem., 91, 3373, (1987).

62. Roscoe, J.M. and Back, R.A.: J. Phys. Chem., 90, 598, (1986).

63. Saito, K.; Kakumoto, T.; and Murakami, I.:

J. Phys. Chem., 88, 1182, (1984).

64. Becker, K.H.; and Klein, Th.: Proceedings, Fourth European Symposium on the Physico-Chemical Behavior of Atmospheric Pollutants, 1986; 320, D. Riedel Publishing Co., Dordrecht, Holland, (1987).

65. Niki, H.; Maker, P.D.; Savage, C.M.; and Breitenbach, L.P.: Int. J. Chem. Kinet., 17, 547, (1985).

66. Colket, M.B. III; Naegeli, D.W. and Glassman, I.: Sixteenth Symposium (International) on Combustion, 1023, The Combustion Institute, 1977.

67. Vandooren, J. and Van Tiggelen, P.J.: Sixteenth Symposium (International) on Combustion, 1133, The Combustion Institute, 1976.

68. Washida, N.; Hatakeyama, S.; and Tagaki, H.:

J. Chem. Phys., 78, 4533, (1983). 
69. Miller, J.A.; Mitchell, R.E.; Smooke, M.D. and Kee, R.J.:

Nineteenth Symposium (International) on Combustion, 181, The Combustion Institute, 1982.

70. Cedarbalk, P.; Hughes, K.J.; Pilling, M.J.; and Proudler, V.K.:

Twenty-Third Symposium (International) on Combustion, Poster 263, The Combustion Institue, 1990.

71. Westmoreland, P.R.: Private Communication.

72. Heineman, P.; Hofmann-Sievert, R.; and Hoyermann, K.:

Twenty-First Symposium (International) on Combustion, 865. The Combustion Institute, 1986.

73. Michael, J.V. and Wagner, A.F.: J.Phys. Chem., 94 ,2453, (1990).

74. Miller, J.A. and Melius, C.F.: Twenty-Second Symposium (International) on Combustion, 1031. The Combustion Institute, 1988.

75. Vinckier, C.; Schaekers, M.; and Peeters, J.:

J. Phys. Chem., 89, 508, (1985).

76. Peeters, J.; Schaekers, M.; and Vinckier, C.:

J. Phys. Chem., 90, 6552, (1982).

77. Harding, L.B.; Schatz, G.C.; and Chiles, R.A.:

J. Chem. Phys.,76, 5172, (1982).

78. Stephens, J.W.; Hall, J.L.; Solka, H.; Yan, W.; Curl, R.F.; and Glass, G.P.: J. Phys. Chem., 91, 5740, (1987).

79. Hwang, S.; Gardiner, W.C. Jr.; Frenklach, M.; and Hidaka, Y.: Combustion and Flame, 67, 65, (1987).

80. Herron, J.T.: J. Phys. Chem. Ref. Data, 17, 966, (1988).

81. Hochgreb, S.; Yetter, R.A.; and Dryer, F.L.: Twenty-Third Symposium (International) on Combustion, 171, The Combustion Institute, 1990.

82. Choudhury, T.K.; Sanders, W.A.; and Lin, M.C.: J. Chem Soc., Faraday Trans. 2, 85, 801, (1989). 
83. Timonen, R.S.; Ratajczak, F.; Gutman, D. and Wagner, A.F.: J.Phys. Chem., 21, 5325, 1987.

84. Batt, L.: Int. Rev. Phys. Chem. 6, 53, 1979.

85. Wantuck, P.J.; Oldenborg, R.C.; Baughcum, S.L.; and Winn, K.R.: J. Phys. Chem., 91, 4653, (1987).

86. Frenklach, M.; Wang, $H$.; and Rabinowitz, M.J.: Prog. Energy Combust. Sci., 18, 47, (1992).

87. Wantuck, P.J.; Oldenborg, R.C.; Baughcum, S.L.; and Winn, K.R.: Chem. Phys. Lett., 138, 548, (1987).

88. Greenhill, P.G.; O'Grady, B.V.; and Gilbert, R.G.: Aust. J. Chem., 39, 1929, (1980).

89. Grotheer, H.H.; Riekert, G.; Walter, D.; and Just, Th.: Twenty-Second Symposium (International) on Combustion, 963. The Combustion Institute, 1988.

90. Tsang, W.: J. Phys. Chem. Ref. Data, 81, 2367, (1987).

91. Rabinowitz, M.J.; Sutherland, J.W., Patterson, P.M.; and Klemm, R.B.: J. Phys. Chèm., 95, 674, (1991).

92. Baldwin, R.R.; Jones, P.N.; and Walker, R.W.: J. Chem. Soc., Faraday Trans. 2: 84, 199, (1988).

93. Cobos, C.J. and Troe, J.: Zeit. Physik. Chemie Neue Folge, 167, 129, (1990).

94. Grotheer, H.H.; Kelm, S.; Driver, H.S.T.; Hutcheon, R.J.; Lockett, R.D.; and Robertson, G.N.: Ber. Bunsenges. Phys. Chem., 26, 1360, (1992).

95. Dean, A.M., and Westmoreland, P.R.: Int. J. Chem. Kinet., 19, 207, (1987).

96. Hidaka,Y.; Nakamura,T.; Tanaka,H.; Inami,K.; and Kawano, H.: Int. J. Chem. Kinet., 22, 701, (1990).

97. Glarborg, P; Miller, J.A.; and Kee, R.J.: Combustion and Flame, 65, 177, (1986). 
98. Dombrowsky, Ch.; Hwang,S.M.; Rohrig,M.; and Wagner, H. Gg.:

Ber. Bunsenges. Phys. Chem., 96,194, (1992).

99. Bohland, T.; Temps, F.; and Wagner, H. Gg.: J. Phys. Chem., 91, 1205, (1987).

100. Zabarnick, S.; Fleming, J.W.; and Lin, M.C.: Twenty-First Symposium (International) on Combustion, 713, The Combustion Institute, 1986.

101. Choudhury, T.K., and Lin, M.C.: Combust. Sci. Tech., 64, 19, (1989)

102. Cathonnet, M. , Boettner, J.C. and James, $H$.:

J. de Chimie Physique, 79, 475, (1982).

103. Spindler, K.G. and Wagner, H. Gg.:

Ber. Bunsenges. Phys. Chem., 86, 119, (1982).

104. Hippler, $H_{\text {.; }}$ Neunaber, $H_{\text {.; }}$ and Troe, J.: Twenty-Fourth Symposium (International) on Combustion, Poster 59, The Combustion Institute, 1992.

105. Keyser, L.: J. Phys. Chem., 84, 1659, (1980).

106. Wine, P.; Semmes, D.; and Ravishankara, A.:

J. Chem. Phys., 75, 4390, (1981).

107. Baldwin, R.R., and Mayor, L.: Trans. Faraday Soc., 57. 1578, (1960).

108. Baldwin, R.R., and Bratten, D.: Eighth Symposium (International) on Combustion, 110, The Combustion Institute, (1962).

109. Baldwin, R.R.; Jackson, D.; Walker, R.W.; and Webster, R.J.: Tenth Symposium (International) on Combustion, 423, The Combustion Institute, (1965).

110. Kurylo, M.; Murphy, J.; Haller, G.; and Curnett, K.: Int. J. Chem. Kinet., 14, 1149, (1982).

111. Greiner, N.: J. Chem. Phys., 72, 406, (1968). 
112. Hay, J.M. and Norrish, R.G.W.: Proc. Roy. Soc. Lond., A288, 1, (1965).

113. Veyret, B. and Lesclaux, R.: J. Phys. Chem., 85. 1918, (1981).

114. Stief, L.J.; Nesbitt, F.L.; and Gleason, J.F.: Abstract of paper pesented at the International Symposium of Gas Kinetics, Assissi, Italy, September 1990.

115. Tsuboi, T.: Jpn. J. Appl.Phys., 15, 159, (1976).

116. Cherian,M.A.; Rhodes,P.; Simpson,R.J.; and Dixon-Lewis,G.: Eighteenth Symposium (International) Combustion, 385, The Combustion Institute, 1981.

117. Langford, A.O. and Moore, C.B.:

J. Chem. Phys., 80, 4211, (1984).

118. Temps, F. and Wagner, H.Gg.: Ber. Bunsenges. Phys. Chem., 88, 410, (1984).

119. Timonen, R.S.; Ratajczak, E.; and Gutman, D.:

J. Phys. Chem., 92, 651, (1988).

120. Bhaskaran, K.A.; Frank, P.; and Just, Th.: Proceedings of the Twelfth Shock Tube Symposium, 503, The Magnes Piere, 1979, Jerusalem.

121. Klatt, M.; Rohrig, M. and Wagner, H.G.:

Ber. Bunsenges. Phys. Chem., 25, 1163, (1991).

122. Grela, M.; Amorebreta, V.T. and Colussi, A.:

J. Phys. Chem., 96, 7013, (1992).

123. Zabarnick, S.; Fleming, J.W.; and Lin, M.C.:

J. Chem. Phys, 85, 4373, (1986).

124. Frank, P.; Bhaskaran, K.A.; and Just, Th.:

J. Phys. Chem., 20, 2226, (1986).

125. Peeters, J. and Vinckier, C.: Fifteenth Symposium (International) on Combustion, 969. The Combustion Institute, 1974. 
126. Troe, J.: J. Chem. Phys., 66, 4758, (1977).

127. Fisher, E.R. and Armentrout, P.B.: J. Phys. Chem., 94, 4396, (1990).

128. Ritter, E.R. and Bozzelli, J.W.: Int. J. Chem. Kinet., 23. 767, (1991). THERM Code Version 4.21.

129. Fletcher, R.A. and Pilcher, G.: Trans. Faraday Soc., 66. 794, (1970).

130. Benson, S.W.: Thermochemical Kinetics, Second Ed., Wiley, 1976.

131. Orville-Thomas, W.J.: Internal Rotation in Molecules, Wiley, 1974.

132. Bott, J.F. and Cohen, N.: Int. J. Chem. Kinet., 23, 1075, (1991).

133. Smith, G.P.: Int. J. Chem. Kinet., 19, 269, (1987).

134. Schmoltner, A.M.; Chu, P.M.; Brudzynski, R.J.; and Lee, Y.T.: J. Chem. Phys., 21, 6926, (1989).

135. Mackie, J.C.: Catal. Rev. - Sci. Eng.: 33, 169, (1991). 


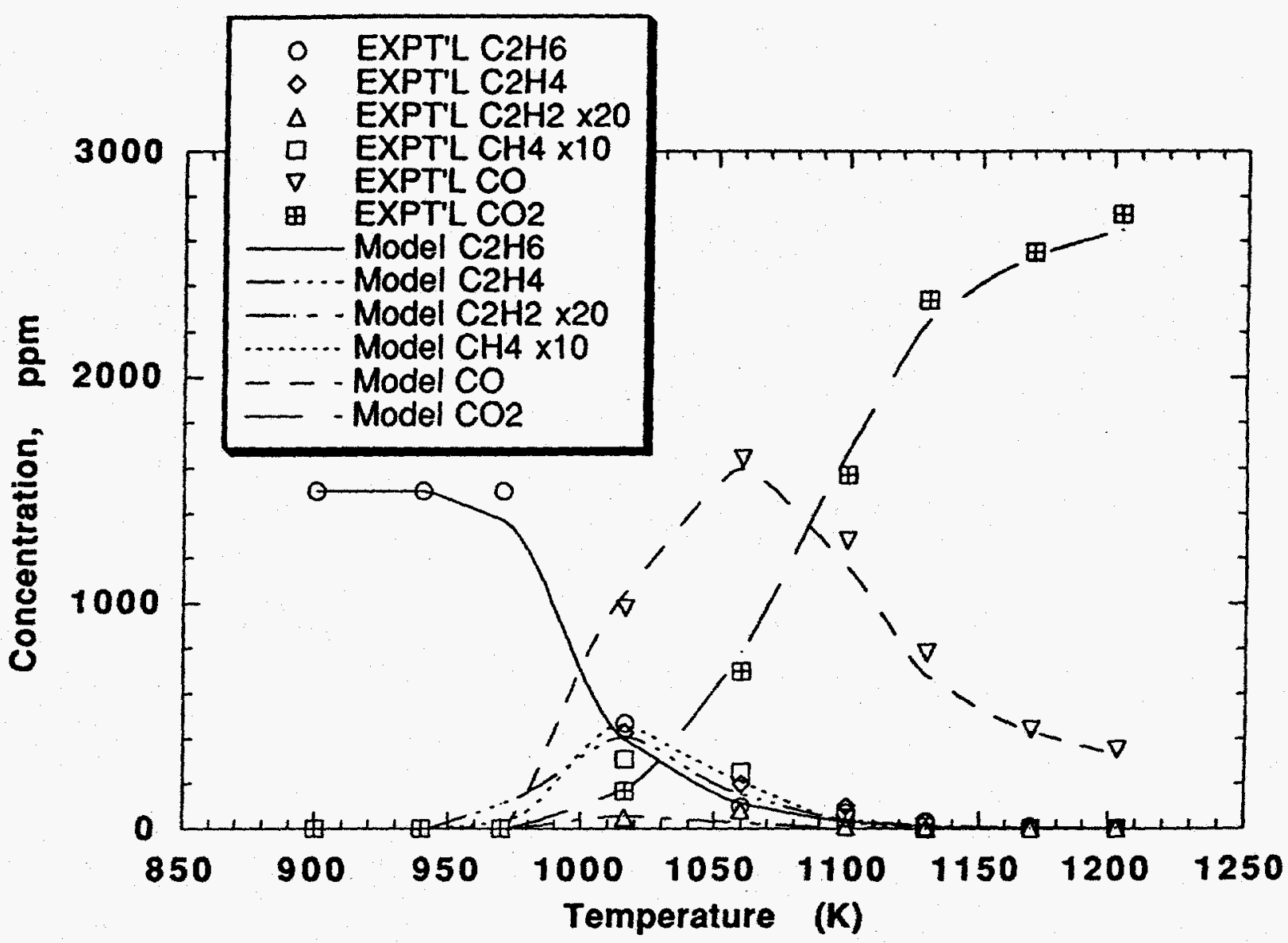

Figure: Oxidation of a $\phi=0.1$ ethane/oxygen/nitogen $(0.15 \%, 5.25 \%, 94.6 \%)$ mixture in the jet stirred reactor [3]

at 1 atmosphere, Symbols represent experimental data while the curves are the modeling results using the compiled ethylene oxidation model listed in Table 3. 


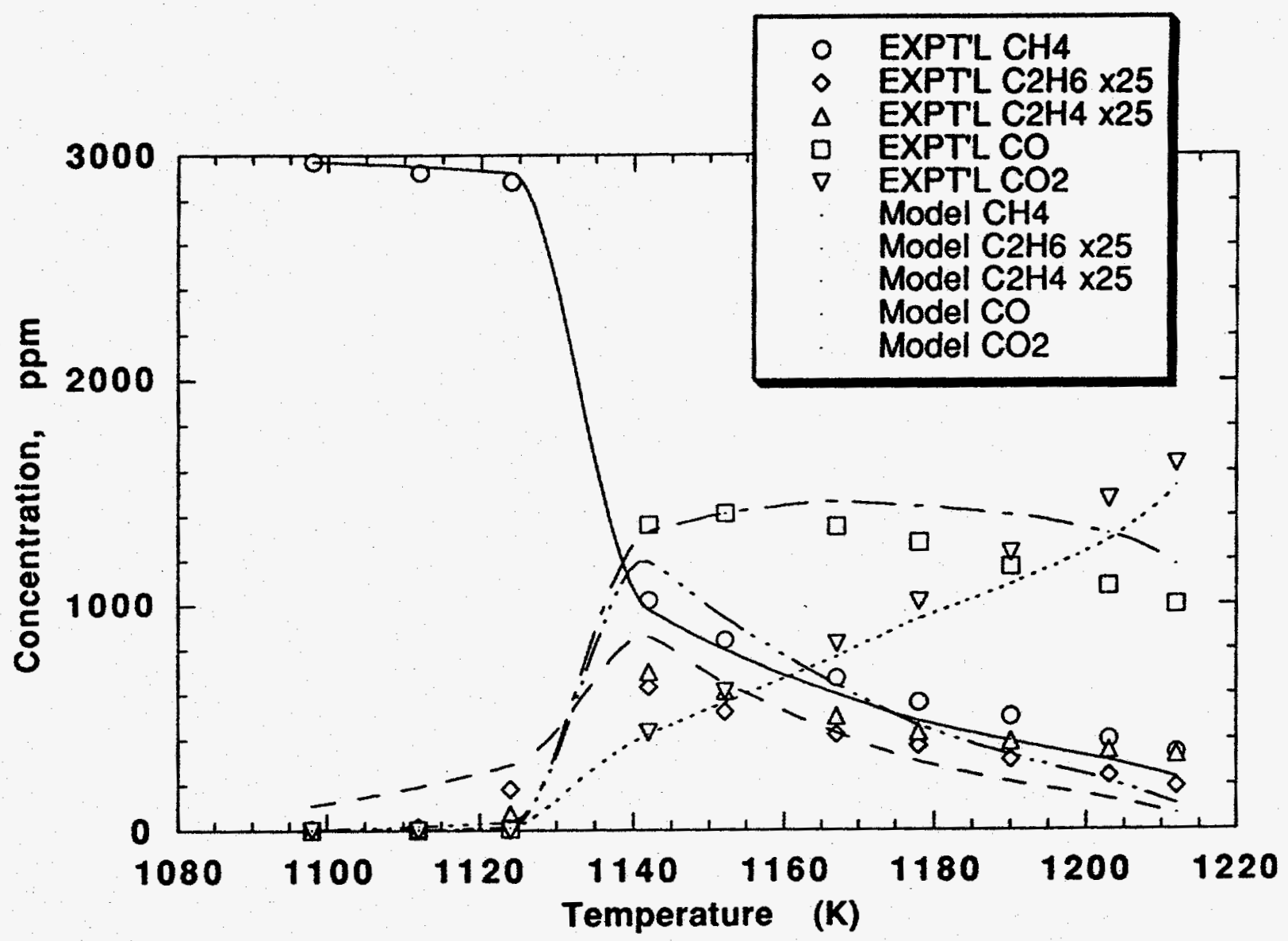

Figure: Oxidation of a $\phi=0.1$ methane/oxygen/nitogen $(0.3 \%, 6.0 \%, 93.7 \%)$ mixture in the jet stirred reactor [47] at 1 atmosphere, Symbols represent experimental data while the curves are the modeling results using the compiled ethylene oxidation model listed in Table 3. 